\title{
COVID-19'un İş Kazası ve Meslek Hastalığı Bakımından Değerlendirilmesi
}

\author{
Seda Arslan Durmuş ${ }^{*}$ C
}

Öz

COVID-19 hastalığı (Korona virüs), Çin'in Wuhan kentinde ortaya çıkmış ve tüm dünyada hızla yayılmıştır. Salgın, çalışma yaşamını derinden etkilemiş ve bu sebeple çalışma hayatına dair birçok yeni düzenleme yapılmıştı. Pandemi döneminde iş sağlığı ve güvenliği hukuku ise işçi-işveren ilişkisine dair en çok etkisini gösteren alanlardan biri olmuştur. İşveren, COVID-19 hastalığının işyerinde yayılmasını engellemek için alması gereken her türlü önlemi almakla yükümlüdür. İşverenin yükümlülüklerine aykırı hareket etmesi, şüphesiz ki sorumluluğunu gündeme getirecektir. Bu noktada COVID-19 hastalı̆ı̆ını iş kazası veya meslek hastalı̆ı bakımından değerlendirilmesi söz konusu olmaktadır. COVID-19'un iş kazası veya meslek hastalı̆ı sayılıp sayılmayacağı hususu, öğretide ve uygulamada tartşmalı konuların başında gelmektedir. COVID-19 virüsüne bağlı bedensel veya ruhsal bir zarar ortaya çıktığında, koşullar varsa iş kazası olarak nitelendirilebilecektir. Bunun gibi COVID-19 hastalığının meslek hastalığı olarak nitelendirilmesi de mümkündür. Sağlık çalışanları bakımından ise konuyu ayırarak incelemekte fayda vardır. Çalışmamızda iş kazası ve meslek hastalığı kavramları üzerinde kısaca durulduktan sonra COVID-19'un neden iş kazası sayılması gerektiği açıklanacaktır.

\section{Anahtar Kelimeler}

COVID-19, İ̧̧ kazası, Meslek hastalı̆̆ı, İ̧ sağlı̆ıı ve güvenliği, İşverenin yükümlülükleri

\section{Evaluation of COVID-19 in Terms of Work Accident and Occupational Disease}

\begin{abstract}
Coronavirus 2019 (COVID-19) emerged in Wuhan, China and spread rapidly around the world, causing an epidemic that has deeply affected working life and resulted in many new regulations regarding working life. Occupational health and safety law is one of the areas that showed the most impact on employee-employer relationships during the pandemic period. Employers are obliged to take every precaution to prevent the spread of COVID-19 in the workplace. The employer is responsible if he acts against his obligations. At this point, COVID-19 is evaluated in terms of work accident or occupational disease. Whether COVID-19 can be counted as a work accident or occupational disease is among the most controversial issues in teaching and practice. When a physical or mental injury resulting from the COVID-19 virus occurs, conditions can be considered a work accident. It is also possible to characterize COVID-19 as an occupational disease. In terms of health workers, it is useful to separate the subject by examining it. In our study, after briefly focusing on the concepts of work accident and occupational disease, we will explain why COVID-19 should be considered as a work accident.
\end{abstract}

\section{Keywords}

COVID-19, General employer responsibility, Occupational disease, Occupational health and safety, Work accident

* Sorumlu Yazar: Seda Arslan Durmuş (Dr. Arş. Gör.), Çukurova Üniversitesi, Hukuk Fakültesi, İş ve Sosyal Güvenlik Hukuku Anabilim Dalı, Adana, Türkiye. E-Posta: arslans@cu.edu.tr Orcid: 0000-0002-0561-3741

Atıf: Arslan Durmus S, “COVID-19’un İş Kazası ve Meslek Hastalığı Bakımından Değerlendirilmesi” (2020) 78(2) İstanbul Hukuk Mecmuası 363. https://doi.org/10.26650/mecmua.2020.78.2.0004 


\section{Extended Summary}

Coronavirus 2019 (COVID-19), which appeared in Wuhan City in the Hubei province of China in December 2019, began to show its effect all over the world in time and has affected many countries globally. COVID-19 first emerged in Turkey on March 11, 2020. During the extraordinary period declared a pandemic, many problems occurred in the field of occupational health and safety. It is essential that the workers are employed in a healthy and safe environment, and employers are obliged to take all precautions on this matter. The main legal problem in the field of occupational health and safety is whether COVID-19 will be considered as a work accident and occupational disease. COVID-19 can be described as a work accident if it occurs within the framework of the conditions written in Law No. 5510.

If an indivudal is infected with the virus while at work, it must be considered as a work accident. It is also within the scope of infection of the worker while carrying out the orders and instructions given by the employer. It is also considered a work accident when the employee contracts COVID-19 from a customer, such as when he goes to repair a faucet in the home of a customer, owing to the work being carried out by the employer. When the worker is sent to another place outside the office as a worker, the situation of being infected with COVID-19 while using public transport will also be counted as a work accident. Even when there is no vehicle provided to the employee, the employer's authority continues. Likewise, if COVID-19 exposure occurs while using public transportation in the milk permit allocated to give milk to the child of the breastfeeding female insured while going to the workplace, a work accident may come up. If transmisstion occurs in a service vehicle provided by the employer, this will also be considered as a work accident. It is possible to replicate these examples, but the important thing is to determine when and how COVID-19 was transmitted to the worker. Instead of counting every COVID-19 occurrance as a work accident, events should be counted when they have a causality link.

Considering the 2- to 14-day incubation period of COVID-19, the virus must be proven to be infected by one of the elements as written in Article 13 of Law No. 5510. To consider it as a work accident, the worker must experience physical or mental harm. The coronavirus may have cause major damage to the lung of the insured, or the insured may have died as a result of his illness. Being infected with the virus may have created a mental disability in the insured. These examples indicate that the insured experienced bodily or mental harm as a result of being infected with the virus.

The concepts of counting a work accident in terms of social security law and counting a work accident in terms of work law are different. According to Law No. 5510, in the case of a work accident, insurance benefits are provided by the Social Security Institution. In order to provide insurance benefits, the employer is 
not required to be at fault. To put it more clearly, qualifying an incident as a work accident may not always result in the employer's legal or criminal liability. For the employer to have legal responsibility from a work accident, an appropriate causal link must be established between the accident and the work performed. The employer will be responsible for not complying with the necessary occupational health and safety obligations. Therefore, if the worker experiences damage owing to COVID-19, the employer will need to be proven defective to be held responsible. The inevitability principle should also be taken into account in determining the responsibility of the worker and the employer.

We believe that the Supreme Court's decision that the death caused by the H1N1 virus (swine flu) as a work accident should be a precedent for COVID-19. In its decision, the Supreme Court stated that there was an appropriate causal link between the subsequent damage and the incident. In COVID-19 disease, depending on the incubation period, it is necessary to acknowledge that the subsequent disease state or death state is a work accident. 


\section{COVID-19’un İş Kazası ve Meslek Hastalığı Bakımından Değerlendirilmesi}

\section{Giriş}

Çin'in Hubei eyaletinin Wuhan şehrinde Aralık 2019'da ortaya çıkan korona virüs, zamanla tüm dünyada etkisini göstermeye başlamış ve küresel olarak birçok ülkeyi etkisi altına almıştır. En son bulunan korona virüsün neden olduğu bulaşıcı hastalık COVID-19 adıyla anılmaktadır¹. Dünya Sağlık Örgütü, COVID-19 salgınını 30 Ocak'ta "uluslararası boyutta halk sağlığı acil durumu" olarak sınıflandırmış, ilk salgının başladığı Çin dışında 113 ülkede COVID-19 vakalarının görülmesi, virüsün yayılımı ve şiddeti nedeniyle 11 Mart 2020'de küresel salgı̀n (pandemi) olarak tanımlamıştır. Türkiye'de de ilk COVID-19 vakası 11 Mart 2020 tarihinde görülmüştür ${ }^{2}$. Virüsün yayılma hızını azaltmak amacıyla ülkemizde birtakım tedbirler alınmış, sokağa çıkma kısıtlamaları söz konusu olmuş, riskli gruplarda yer alanlar bakımından özel koruyucu düzenlemeler getirilmiştir.

İlk vakanın tespit edilmesinden bu yana geçen süreçte işyerleri ve çalışanlar, korona virüsten en çok etkilenenlerin başında gelmektedir. Pandeminin halen sürmesi sebebiyle de çalışma hayatını etkilemeye devam etmektedir. Kimi işyerlerinde üretim tamamen veya kısmen durma noktasına gelmiş iken kimi işyerlerinde ise üretim daha da çok artmıştır. COVID-19'dan kaynaklı olası hukuki sorunları çözebilmek adına mevzuatımızda yeni/geçici hukuki düzenlemeler yapılmıştır. Ancak pandemi ilan edilen olağanüstü dönem için iş sağlığı ve güvenliği alanına ilişkin sorunlar ve soru işaretleri giderilmiş değildir. Şüphesiz ki üretimin en asli unsuru olan işçilerin sağlıkları, her şeyden önce gelmelidir. İş sağlığg ve güvenliğine ilişkin işverenin yükümlülükleri de bu noktada oldukça önemlidir. İşçilerin sağlıklı ve güvenli bir ortamda çalıştırılmaları esas olup işveren bu konuda üstüne düşen her türlü önlemi almakla yükümlüdür.

İş sağlığı ve güvenliği alanına ilişkin en temel hukuki sorun COVID-19'un iş kazası ve meslek hastalığı sayılıp sayılmayacağı hususudur. Güncel gelişmelere bakıldığında tartışmalı uygulamaların olduğu görülmektedir. Sosyal Güvenlik Kurumu Başkanlığı Emekli Hizmetleri Genel Müdürlüğü’nün 7.5.2020 tarihli ve 2020/12 say1l Genelgesi'nde “COVID-19 virüsünün bulaşıcı bir hastalık olduğu dikkate alındı̆̆ında, söz konusu salgına maruz kalan ve să̆lık hizmet sunucularına müracaat eden sigortalılara hastalık kapsamında provizyon alınması gerektiği" ifade edilmiştir. Söz konusu Genelge ile Sosyal Güvenlik Kurumu, COVID-19'a maruz kalan sigortalıları "iş kazası ve meslek hastalığı sigortası” kapsamında değil

\footnotetext{
$<$ https://www.who.int/health-topics/coronavirus\#tab=tab_1> Erişim Tarihi 13 June 2020.

T.C. Sağlık Bakanlığı Halk Sağlığı Genel Müdürlüğü, ‘COVID-19 (Sars-Cov-2 Enfeksiyonu), Genel Bilgiler, Epidemioloji ve Tanı, Bilimsel Danışma Kurulu Çalışması', Ankara, (1 Haziran 2020) $5<\mathrm{https://covid19bilgi.saglik.gov.tr/depo/}$ rehberler/covid-19-rehberi/COVID-19_REHBERI_GENEL_BILGILER_EPIDEMIYOLOJIVE_TANI.pdf $>$ Erişim Tarihi 13 June 2020.
} 
de "hastalık sigortası" kapsamında değerlendirmiştir. Şüphesiz ki idari kararlar yargı kararlarını bağlamamaktadır. Bu sebeple COVID-19 virüsünün Genelge ile hastalık kapsamına alınmasının bağlayıcı olmadığı kanaatindeyiz.

Nitekim Yargitay 21. Hukuk Dairesinin 15.04.2019 tarihli emsal diyebileceğimiz bir kararında ${ }^{3}$, tır şoförü olan işçinin işveren tarafından Ukrayna'ya sefere gönderildiği, H1N1 virüsünün (domuz gribi) bulaşması sonucu daha sonra ölümün gerçekleştiği olayda, işveren tarafindan yürütülmekte olan iş nedeniyle Ukrayna'ya yapılan sefer sırasında bulaştığı rapor kapsamından anlaşılan H1N1 virüsüne bağlı olarak, meydana gelen ölüm, oy çokluğu ile iş kazası olarak değerlendirilmiştir. Yargıtayın bu yaklaşımının Korona virüsten kaynaklı ölüm olaylarında da sürdürmesi gerektiği ve virüsün çalışan ve işyeri ile ilişkili olduğu ispatlanabildiği ölçüde meydana gelen zararların iş kazası sayılması gerektiği kanaatindeyiz. Aynı şekilde özellikle sağlık çalışanları bakımından sigortalı, Korona virüsten kaynaklı bedensel veya ruhsal bir zarara uğrarsa meslek hastalığı kapsamında değerlendirilebilir. COVID-19 hastalığının iş kazası veya meslek hastalığı olarak değerlendirilmesinin yapılabilmesi için öncelikle 5510 sayılı Sosyal Sigortalar ve Genel Sağlık Sigortası Kanunu ${ }^{4}$ ve 6331 sayılı İş Sağlığı ve Güvenliği Kanunundaki ${ }^{5}$ düzenlemelere bakılacak ve unsurlar k1saca teker teker incelenecektir.

\section{II. İş Kazası Kavramı}

\section{A. Genel Olarak}

Kaza kavramı, borçlar hukuku, iş hukuku ve sosyal güvenlik hukuku bakımından ayrı kavramları ifade eder ve hukuki sonuçları da farklıdır ${ }^{6}$. Genel tanımıyla kaza, kişinin isteği dışında, öngörülemeyen, dıştan gelen bir etkenle, ani olarak ortaya çıkan bir olaydır7. İş kazasının söz konusu olabilmesi için, insan vücudunun zarar görmesi gerekir. Bu sebeple eşyaya ilişkin zararlar, iş kazası olarak nitelendirilemezler ${ }^{8}$

\footnotetext{
Yargitay 21 HD, 5018/2931, 15.04.2019<www.kazanci.com>.

4 Sosyal Sigortalar ve Genel Sağlık Sigortası Kanunu, Kanun Numarası: 5510, Kabul Tarihi: 31.05.2003, RG 16.06.2006/26200.

İş Sağlığı ve Güvenliği Kanunu, Kanun Numarası: 6331, Kabul Tarihi: 20.06.2012, RG 30.06.2012/28339.

6 Ali Güzel, Ali Rıza Okur and Nurșen Caniklioğlu, Sosyal Güvenlik Hukuku (18th edition, Beta 2020) 354; Can Tuncay and Ömer Ekmekçi, Sosyal Güvenlik Hukuku Dersleri, (20th edition, Beta 2019) 390-391; Nurșen Caniklioğlu, 'Sosyal Sigorta Türleri Açısından Yargıtayın 2002 Yılı Kararlarının Değerlendirilmesi’, (2004) İş Hukuku ve Sosyal Güvenlik Hukuku Türk Milli Komitesi 339, 342; Ali Nazım Sözer, Türk Sosyal Sigortalar Hukuku, (4th edition, Beta 2019) 335-337; Zeki Okur, 'Yargıtay Kararları Çerçevesinde İș Kazası' (2013), VII. Ulusal İșçi Sağlığı ve İș Güvenliği Kongresi Bildiriler Kitabı 18-20 Nisan 2013, 325, 326; Sabahattin Yürekli, 'Çalışma Hayatında Koronavirüs (COVID-19) Salgınının Etkileri' (2020) 19(38) İstanbul Ticaret Üniversitesi Sosyal Bilimler Dergisi, COVID-19 Hukuk Özel Sayıs1, 34, 42.

Güzel, Okur and Caniklioğlu (n 6) 361; Tuncay and Ekmekçi (n 6) 394; Haluk Hadi Sümer, Işs Sağlı̆̆ı ve Güvenliği Hukuku (3th edition, Seçkin 2019) 91; Levent Akın, 'COVID-19’un İş İlişkilerine Olası Etkileri’ (2020) 34(3) Çimento İşveren Dergisi, 16, 21; Yürekli (n 6) 43.

$8 \quad \operatorname{ibid} 365$.
} 
İş kazası kavramı hem 6331 sayılı İş Sağlığı ve Güvenliği Kanununda hem de 5510 sayılı Sosyal Sigortalar ve Genel Sağlık Sigortası Kanununda düzenlenmiştir. İş kazaları, sadece işçi-işveren ilişkisi bağlamında düşünülemez. Toplumu derinden etkileyen, uluslararası belgelerde ve TC Anayasasında korunan yaşama hakkı, en temel insan hakkı olup iş kazaları ile ihlal edilmemelidir. Sonuçları bakımından sadece iş hukuku, iş sağlığı ve güvenliği hukuku ile ilgili olmayan iş kazaları, aynı zamanda hem sosyal güvenlik hukuku boyutuyla hem de borçlar hukuku ve ceza hukuku boyutlarıyla da ele alınmalıdır. İş kazaları ve meslek hastalıklarını en aza indirmek için öncelikle devlete, işverenlere, sendikalara ve nihayet çalışanlara büyük görevler düşmektedir. Her iş kazası, kazaya uğrayana, ailesine, işverene ve topluma maddi manevi büyük kayıplar getirmektedir. Önleyici tedbirlere ağırlık vermek, öncelikli amaç olmalıdır. Bu sebepledir ki 6331 sayılı İş Sağlığı ve Güvenliği Kanunu, 2012 yılında önleme amacına yönelik bir Kanun olarak yürürlüğe girmiştir9.

5510 sayılı Sosyal Sigortalar ve Genel Sağlık Sigortası Kanunu bakımından iş kazası kavramı ile 6331 sayılı İş Sağlı̆ı ve Güvenliği Kanunu bakımından iş kazası kavramları birbirinden farklıdır. İşverenin iş kazasından sorumlu olabilmesi için, sorumluluk hukukunun genel ilkeleri doğrultusunda işçinin gördüğü iş veya işverenin yürüttüğü iş ile kaza arasında uygun nedensellik bağı olmalıdır ${ }^{10}$. Bir başka ifadeyle, işveren, ancak iş sağllğ 1 ve güvenliği yükümlülüklerini yerine getirmemişse, oluşan zarardan sorumlu tutulabilecektir. İş sağlığı ve güvenliği yükümlülükleri yerine getirilmiş ve işçinin gördüğü iş ile nedensellik bağ 1 içinde olmayan ancak işyerinde meydana gelen bir kaza da 5510 sayılı Kanun bakımından iş kazası sayılacaktır. Ancak böyle bir durumda işverenin sorumluluğu söz konusu olmayacaktır. Kisaca iş hukuku anlamında her kaza, sosyal güvenlik hukuku anlamında da bir iş kazasıdır. Bununla birlikte sosyal güvenlik hukukuna göre bir iş kazası, iş hukuku bakımından iş kazası olmayabilir" ${ }^{11}$. Sigortalının kendi kusuru sonucu uğradığı kaza da, iş kazası sayılmalıdır ${ }^{12}$.

5510 sayılı Kanun madde 13'te bazı hal ve durumlar sayılarak kaza olayının belirtilen durumlardan birinde meydana gelmesinin iş kazası olduğu ifade edilmiştir. Bir kaza, sosyal güvenlik hukuku bakımından bir iş kazası ise, 5510 sayılı Kanunda öngörülen sigorta yardımlarına hak kazanacaktır. 5510 sayılı Kanun madde 13'e göre iş kazası; “a) Sigortalının işyerinde bulunduğu sırada, b) İşveren tarafindan yürütülmekte olan iş nedeniyle sigortal kendi adına ve hesabına bağımsız çallşlyorsa yürütmekte olduğu iş nedeniyle, c) Bir işverene bağll olarak çallş̧an

\footnotetext{
ibid $351,356$.

10 Güzel, Okur and Caniklioğlu (n 6) 359 vd.; Tuncay and Ekmekçi (n 6) 391; Sarper Süzek, İ̧̧ Hukuku (16th edition, Beta 2018) 425; Erdem Özdemir, İs Sağllğı ve Güvenliği Hukuku, (Vedat 2014) 519; Levent Akın, 'İşverenin İşçiyi Gözetme Borcundan Doğan Hukuki Sorumluluğunda Uygun Nedensellik Bağı’ (Karar İncelemesi) (Mart 2011) Çimento İşveren Dergisi, 26, 34; Sümer (n 7), 208-209.

11 ibid 391; Levent Akın, İş Kazasından Doğan Maddi Tazminat (Yetkin 2001) 44-45; ibid 211.

12 Güzel, Okur and Caniklioğlu (n 6) 366.
} 
sigortalının, görevli olarak işyeri dışında başka bir yere gönderilmesi nedeniyle asıl işini yapmaksızın geçen zamanlarda, d) Bu Kanunun 4 üncü maddesinin birinci fikrasının (a) bendi kapsamındaki emziren kadın sigortalının, iş mevzuatı gereğince çocuğuna süt vermek için ayrılan zamanlarda, e) Sigortalıların, işverence sağlanan bir taşıtla işin yapıldiğı yere gidiş gelişi sırasında, meydana gelen ve sigortaliyı hemen veya sonradan bedenen ya da ruhen engelli hâle getiren olaydır". Sosyal güvenlik hukuku bakımından iş kazası denilebilmesi için kazanın 5510 sayılı Kanun madde 13'te sayılan beş durumdan birinde gerçekleşmiş olması gerekir. Bu sebeple 5510 sayılı Kanun madde 13 'te yer verilen iş kazasının unsurlarının teker teker ele alınmasında fayda vardır. 5510 sayılı Kanun madde 13 'te iş kazası olduğu belirtilen hal ve durumlar şunlardır:

\section{B. İş Kazasının Unsurları}

\section{Sigortalı Olma}

İş kazasının unsurlarından ilki, kazaya uğraya kişinin 5510 sayılı Kanun hükümlerine göre sigortalı sayılmasıdır. 5510 sayılı Kanun madde 3/I, 6'ya göre sigortal1, kısa ve/veya uzun vadeli sigorta kolları bakımından adına prim ödenmesi gereken veya kendi adına prim ödemesi gereken kişidir. Sigortalı kavramı, 506 sayılı Kanuna göre daha geniş bir kavramı ifade etmektedir ${ }^{13}$. İş kazası ve meslek hastalığ1 sigorta kolu, kısa vadeli sigorta kolları arasındadır (5510 sayılı Kanun madde 3/I-4). 5510 sayılı Kanunun kısa vadeli sigorta kollarına ilişkin hükümleri ise aynı Kanunun dördüncü maddesinin birinci fikrasının (c) bendi kapsamında sigortalı sayılanlara bu kapsamda oldukları sürece uygulanmaz (5510 sayılı Kanun madde 4/VI). Dolayısıyla iş kazası ve meslek hastalığ sigorta kolu, 5510 sayılı Kanun madde 4/I, a ve madde 4/I, b kapsamına giren sigortalılar hakkında uygulanacak; madde 4/I, c bendine giren sigortalılar hakkında uygulanmayacaktır. O halde kazanın 5510 sayılı Kanun bakımından bir iş kazası sayılabilmesi için, öncelikle bir iş sözleşmesine bağlı olarak çalışan sigortalı veya bağımsız çalışan bir sigortalı olmak gerekir. Kamu görevlileri, için kısa vadeli sigorta kolları bakımından 5434 sayılı Emekli Sandığı Kanunu uygulanacaktır.

İş kazası ve meslek hastalığı sigorta kolu ayrıca 5510 sayılı Kanun madde 5 'te düzenlenen iş kazası ve meslek hastalığı sigortasının kapsamında olduğu belirtilen kişiler hakkında da uygulama alanı bulur. Madde 5'te düzenlenen iş kazası ve meslek hastalı̆̆ı sigortasının kapsamında olduğu belirtilen kişiler şunlardır:

İş sözleşmesi ile çalışmamakla birlikte, ceza infaz kurumları ile tutukevleri bünyesinde oluşturulan tesis, atölye ve benzeri ünitelerde çalıştırılan hükümlü

3 Bağımlı çalışanlar yanında bağımsız çalışanlar da sigortalı sayılacaktır; ancak bağımsız çalışanlar, sadece yürütmekte oldukları iş sebebiyle kazaya uğramaları durumunda bu sigortadan faydalanacaklardır, ibid 362 . 
ve tutuklular (5510 sayılı Kanun madde 5/I, a). Meslekî Eğitim Kanununda belirtilen aday çırak, çırak ve işletmelerde meslekî eğitim gören öğrenciler (5510 sayılı Kanun madde 5/I, b). Meslekî ve teknik ortaöğretim ile yükseköğrenimleri sırasında staja tabi tutulan öğrenciler, mesleki ve teknik ortaöğretim sırasında tamamlayıcı eğitim ya da alan eğitimi gören öğrenciler, kamu kurum ve kuruluşları tarafından desteklenen projelerde görevli bursiyerler ile 2547 sayılı Yükseköğretim Kanununun 46'ncı maddesine tabi olarak kısmi zamanlı çalıştırılan öğrencilerden aylık prime esas kazanç tutarı, günlük prime esas kazanç alt sınırının otuz katından fazla olmayanlar (5510 sayılı Kanun madde 5/I, b). Harp malulleri ile 2330 sayılı Nakdi Tazminat ve Aylık Bağlanması Hakkında Kanuna veya 2330 sayılı Kanun hükümleri veya 5434 sayılı Kanunun 56'ncı maddesi uygulanarak aylık bağlanmasını gerektiren Kanunlara göre vazife malullüğü aylığı bağlanmış malullerden, madde 4/I, a ve b bentleri kapsamında sigortalı olarak çalışmaya başlayanların aylıkları kesilmeksizin madde 4/I, a ve b bentleri kapsamında çalışanlar (5510 sayılı Kanun madde 5/I, c). Türkiye İş Kurumu tarafından düzenlenen meslek edindirme, geliştirme ve değiştirme eğitimine katılan kursiyerler (5510 sayılı Kanun madde 5/I, e). Ülkemiz ile sosyal güvenlik sözleşmesi olmayan ülkelerde iş üstlenen işverenlerce yurt dışındaki işyerlerinde çalıştırılmak üzere götürülen Türk işçileri (5510 say1l1 Kanun madde 5/I, g).

Tarım veya orman işlerinde iş sözleşmesiyle süreksiz olarak çalışanlar da 5510 sayılı Kanun madde 4/1, a bendi kapsamında sigortalı sayılırlar. Bu kişiler hakkında da iş kazası ve meslek hastalığı sigorta kolu uygulanır (5510 sayılı Kanun ek madde 5/IV). Ayrıca ev hizmetlerinde çalışanlar ile konut kapıcılığ işyerlerinde çalıştırılan sigortalılar da iş kazası ve meslek hastalığı sigortasından yararlanacaklardır (5510 sayılı Kanun ek madde 9).

Sigortalılık niteliğinin kazanılması için, sigortalılık niteliğinin edinilebileceği bir işte çalışmaya başlamak yeterlidir. Bu kişilerin Sosyal Güvenlik Kurumuna bildirilmemiş olmaları, bu niteliklerini ortadan kaldırmaz. Dolayısıyla Sosyal Güvenlik Kurumuna bildirilmemiş bir kişi, kazaya uğrasa dahi uğradığı kaza, iş kazası olarak sayılabilecektir ${ }^{14}$.

İş kazası ve meslek hastalıkları sigorta kolundan yararlanabilmek için, sigortalının çalışmaya başlaması yeterlidir. Ayrıca belli bir süre sigortalılık veya belirli bir süre prim ödemiş olma koşulunun gerçekleşmesi aranmayacaktır ${ }^{15}$. Bu yönüyle belirli bir süre sigorta primi bildirilmesinin şart olduğu hastalık sigortası kolunun uygulanmasına göre daha avantajlıdır.

ibid 362; Sümer (n 7) 91.

15 ibid 362; ibid 91. 


\section{Kazaya Uğrama}

\section{a. Sigortalının İşyerinde Bulunduğu Sırada Kazaya Uğraması}

Sigortalının işyerinde bulunduğu sırada meydana gelen kazalar, başka bir koşula gerek duyulmaksızın iş kazası sayılırlar. Böyle bir durumda ayrıca kaza ile iş arasında uygun nedensellik bağının bulunması gerekmez ${ }^{16}$. 5510 sayılı Kanun madde 11'e göre, işyeri, sigortalı sayılanların maddî olan ve olmayan unsurlar ile birlikte işlerini yaptıkları yerlerdir. İşyerinde üretilen mal veya verilen hizmet ile nitelik yönünden bağl1lığı bulunan ve aynı yönetim altında örgütlenen işyerine bağlı yerler, dinlenme, çocuk emzirme, yemek, uyku, yıkanma, muayene ve bakım, beden veya meslek eğitimi yerleri, avlu ve büro gibi diğer eklentiler ile araçlar da işyerinden sayllır. Görüldüğü üzere, sadece asıl işyerinde meydana gelen kazalar değil, asıl işyerine bağlı yerlerde meydana gelen kazalar da iş kazası sayılacaktır.

Sigortalının uğradığı kazanın iş kazası sayılabilmesi için mutlaka iş saatleri içinde meydana gelmesi de gerekmez. İşyerinde meydana gelen kaza, ara dinlenmesi sırasında da gerçekleşse iş kazası olarak kabul edilebilecektir ${ }^{17}$.

\section{b. İşveren Tarafından Yürütülmekte Olan İş Nedeniyle Meydana Gelen Kazalar}

İşveren tarafından işyeri dışında da birtakım işlerin yürütülmesi mümkündür. İşveren tarafından yürütülmekte olan işin sonucunda ortaya çıkan kazalar, işyeri dışında da meydana gelse iş kazası kabul edilecektir. Bu sebeple işçinin işini yurt dışında yerine getirdiği bir sırada geçirdiği kaza da iş kazası olarak kabul edilebilecektir ${ }^{18}$.

\section{c. Görevli Olarak Başka Yere Gönderilen Sigortalının Uğradığı Kaza}

Bir işverene bağlı olarak çalışan sigortalının, görevli olarak işyeri dışında başka bir yere gönderilmesi nedeniyle asıl işini yapmaksızın geçen zamanlarda meydana gelen kazalar da iş kazası sayılmıştır. Sigortalı, işverenin işi için başka bir yere gittiğinden işverenin otoritesi altındadır. Bu sebeple sigortalının asıl işini yapmaksızın geçen zamanlarda meydana gelen kazalar da iş kazası sayılacaktır. Asıl işin yapılmadığı zamanlar, işyerine gidiş geliş yolculuğunu kapsadığ gibi işçinin özel yaşamındaki yemek, uyku, eğlence vb. boş zamanları da madde kapsamında kalmalıdır ${ }^{19}$.

\footnotetext{
Sözer (n 6) 339; ibid 92.

Güzel, Okur and Caniklioğlu (n 6) 367-368; ibid 344-345; ibid 92, 94.

ibid 94.

Güzel, Okur and Caniklioğlu (n 6) 371; Sözer (n 6) 347; ibid 95.
} 


\section{d. Süt İzninde Meydana Gelen Kazalar}

Emziren kadın sigortalının, iş mevzuatı gereğince çocuğuna süt vermek için ayrılan zamanlarda meydana gelen kazalar da iş kazası sayılacaktır. 4857 sayılı İş Kanunu ${ }^{20}$ madde 74/VII'ye göre kadın işçilere bir yaşından küçük çocuklarını emzirmeleri için günde toplam bir buçuk saat süt izni verilir. Bu sürenin hangi saatler arasında ve kaça bölünerek kullanılacağını işçi kendisi belirler ve bu süre günlük çalışma süresinden sayılır. Bu süre içinde kadın işçi evde veya yolda bir kazaya uğrar ise bu kaza, iş kazası sayılmalıdır ${ }^{21}$.

\section{e. İşverence Sağlanan Bir Taşıtla İşin Yapıldığı Yere Gidiş Geliş Sırasında Meydana Gelen Kaza}

Sigortalıların, işverence sağlanan bir taşıtla işin yapıldı̆̆ı yere gidiş gelişis sırasında, meydana gelen kazalar, iş kazası sayılacaktır. Hükümde vurgu yapılan husus, aracın işverence sağlanmış olması ve kazanın bu araçla işe gidiş-geliş sırasında meydana gelmiş olmasıdır. İşveren, iş̧̧ilere servis aracını işin niteliği gereği veya sosyal yardım yapılması amacıyla sağlayabilir. Hangi amaçla olursa olsun eğer kaza işverence sağlanan bir araçla ve işin yapıldığ 1 yere gidiş geliş sırasında ortaya çıkmışsa, iş kazası olarak değerlendirmek gerekecektir ${ }^{22}$. Kazanın iş kazası sayılması için, aracın işverenin mülkiyetinde olması zorunlu değildir ${ }^{23}$. İşveren, aracı kiralamış dahi olsa kaza işin yapıldığ1 yere gidiş geliş sırasında meydana gelmiş ise iş kazası olarak nitelendirilebilecektir.

\section{Bedensel veya Ruhsal Bir Zarara Uğrama}

Meydana gelen bir kazanın iş kazası olarak sayılabilmesi için, Kanunda sayılan durumlarda ortaya çıkmasının yanında sigortalıyı hemen veya sonradan bedenen ya da ruhen engelli hâle getirmesi gerekmektedir. Bedensel zarar; kırık, çıkık, yanık, kesik, beyin kanaması, iç kanama ve hatta ölüm de olabilir. Ancak dikkat edilmesi gereken, uğranılan zararın en azından sosyal sigorta yardımlarının Kurumca sağlanmasını gerektirecek nitelikte ve derecede olmasıdır ${ }^{24}$.

İş kazası sonunda sigortalının bedensel zarar görmesi yanında ruhsal zarar görmesi de mümkündür. Ayrıca zarar, iş kazasının meydana geldiği anda ortaya çıkabileceği gibi kazadan sonra da ortaya çıkabilir. Bir olayın iş kazası olarak değerlendirilmesi için mutlaka sigortalının bedensel ya da ruhsal bir zarara uğraması gerekmekte olup

\footnotetext{
İş Kanunu, Kanun Numarasi: 4857, Kabul Tarihi: 22.5.2003, RG 10.6.2003/25134.

Sözer (n 6) 348.

Güzel, Okur and Caniklioğlu (n 6) 373-374; Tuncay and Ekmekçi (n 6) 407; Sözer (n 6) 349; Sümer (n 7 ) 97.

ibid 373; ibid 407; Sözer (n 6) 350; ibid 97.

24 Gündelik iş yaşamında sıkça karşılaşılan yaralar, sıyrıklar iş kazası olarak nitelendirilmeyecektir, ibid 374; ibid 412; Sözer (n 6) 353 .
} 
bedensel veya ruhsal zararlar dışındaki mal kaybına neden olan olaylar, iş kazası olarak değerlendirilmeyecektir ${ }^{25}$.

\section{Kaza ile Sigortalının Uğradığı Zarar Arasında Nedensellik Bağının Bulunması}

İş kazası ile sigortalının uğradığı zarar arasında bir ilişkinin, uygun neden-sonuç bağlantısının olması gerekir. Kaza ile zarar arasındaki uygun nedensellik bağının tespiti her zaman kolay olmayabilir. Hayatın olağan akışına göre zarar, sigortalının maruz kaldığ kazanın sonunda gerçekleşmiş olmalıdır' ${ }^{26}$. Kaza ile zarar arasında uygun nedensellik bağının olup olmadığı somut olayın özelliklerine göre değişecektir ${ }^{27}$.

Nedensellik bağının tespitinde "işverenin otoritesi altında olma" belirleyici bir ölçüt olarak değerlendirilebilir. Buna göre sigortalı eğer işverenin emir ve talimatı altında bulunduğu sırada bir kazaya uğramışsa, nedensellik bağı gerçekleşmiş olacağ1 için, kaza da iş kazası sayılabilecektiri ${ }^{28}$.

\section{COVID-19’un İş Kazası Olarak Değerlendirilmesi}

\section{A. İşverenin Yükümlülükleri}

\section{Genel Olarak}

İşverenin işçiyi koruma (gözetme) borcu, işverenin en temel yükümlülüklerinden biridir. Türk Borçlar Kanunu ${ }^{29}$ madde 417 'de işverenin işyerinde iş sağlığı ve güvenliğinin sağlanmasi için gerekli her türlü önlemi almak, araç ve gereçleri noksansız bulundurmakla yükümlü olacağ1 düzenlenmiştir. İşverenin, kanuna ve sözleşmeye aykırı davranışı nedeniyle işçinin ölümü, vücut bütünlüğünün zedelenmesi veya kişilik haklarının ihlaline bağlı zararların tazmini ise sözleşmeye aykırılıktan doğan sorumluluk hükümlerine tabi olacaktır (TBK madde 417/son). Buna göre işverenin, işçiyi koruma borcunu yerine getirmemesi sebebiyle ortaya çıkan iş kazası ve meslek hastalıklarından sorumluluğu doğacaktır.

İşverenin iş sağlığı ve güvenliğine ilişkin yükümlülükleri 6331 sayılı İş Sağlığ1 ve Güvenliği Kanunu ile somutlaştırılmıştır. 6331 sayılı Kanunda işverenin genel yükümlülükleri madde 4'te sayılmış ve aslında iş sağlığı ve güvenliğine ilişkin olarak işverenin yapması gerekenler Kanunun bütününde belirtilmiştir. 6331 sayılı Kanunun

\footnotetext{
25 Sigortalıya takılan ve organ görevi yapan protezlerde meydana gelen zararlar, iş kazası olarak kabul edilmelidir, ibid 375; ibid 412; Sözer (n 6) 352-353; Okur (n 6) 329.

26 ibid 375; ibid 410; Sümer (n 7) 98; Yürekli (n 6) 43; Okur (n 6) 330.

27 ibid 376; ibid 397; ibid 44.

28 ibid 375-376.

29 Türk Borçlar Kanunu, Kanun Numarası: 6098, Kabul Tarihi: 11.01.2011, RG 04.02.2011/27836.
} 
temelinde “önlemenin ödemeden daha ucuz olduğu” yaklaşımı benimsenerek önleme ve koruma politikası yer almaktadır ${ }^{30}$. Buna göre işveren, iş kazası veya meslek hastalığı meydana geldikten sonra değil, iş kazası veya meslek hastalığı meydana gelmeden önce gerekli sistemi kurma yükümlülüğü altındadır.

İşveren hem TBK hem de 6331 sayılı Kanun uyarınca bilim, teknik ve tecrübenin o anda ulaştığı son duruma göre gerekli iş sağlığı ve güvenliği önlemlerini almak zorundadır. Buna göre işverenler, iş sağlığı ve güvenliği önlemlerini sürekli izlemek, geliştirmek; tehlikeli olanı tehlikesiz olanla değiştirmekle yükümlüdürler. $\mathrm{Bu}$ doğrultuda işveren, iş sağlığı ve güvenliği mevzuatında öngörülmemiş önlemleri de almalı, bilimsel ve teknolojik gelişmelerin gerekli kıldığı bütün iş sağlığı ve güvenliği önlemlerini uygulamalıdır ${ }^{31}$.

\section{2. İşverenin COVID-19 Özelinde Yükümlülükleri}

İşverenin iş sağlığı ve güvenliği konusunda göstermesi gereken özen derecesi, tehlike arttığı ölçüde artmaktadır. COVID-19'un Dünya Sağlık Örgütü tarafından pandemi ilan edilen salgın bir hastalık olduğu, virüsün yayılma hızı, öldürücülüğü dikkate alındığında, işverenin göstermesi gereken özen yükümlülüğü de en üst seviyeye çıkmalıdır. İşveren, bu konuda gerekli önlemleri almazsa, yükümlülüklerini yerine getirmezse, özen yükümlülüğünü de yerine getirmemiş olacaktır. Zira salgın hastalık halinde toplumsal risk söz konusudur. Toplumsal risk konusunda da iş ile ilgisi kurulabildiği sürece işverenin iş sağlığı ve güvenliği yükümlülükleri devam etmektedir. COVID-19 salgın hastalığı, işyerinde bulaşma riskini artırabildiği sürece, COVID-19'un iş ile ilgisi kurulabilir ${ }^{32}$.

İşveren gözetme borcu gereği, dünyayı tehdit eden salgın hastalığın işyerinde bulaşma riskini önleyecek önlemler almalıdır. Hatta olağanüstü dönem dikkate alınarak İş Sağlığı ve Güvenliği Kanununda yazılan standartların üzerine çıkılmalı, iş güvenliği profesyonelleri ile sık sık görüşülmeli ve önlemler sürekli yenilenmelidir. TC Aile, Çalışma ve Sosyal Hizmetler Bakanlığı "İşyerlerinde Koronavirüse (COVID-19) Karşı Alınması Gereken Önlemler”i yayınlamıştır³. Örneğin, COVID-19 ile ilgili

\footnotetext{
30 Nuri Çelik, Nurşen Caniklioğlu and Talat Canbolat, $\dot{I}_{S ̧}$ Hukuku Dersleri (32th edition, Beta, 2019) 376; Nurşen Caniklioğlu ‘6331 Sayılı İş Sağlığı ve Güvenliği Kanununda Öngörülen İşveren Yükümlülükleri' (2012) Türkiye Toprak, Seramik, Çimento ve Cam Sanayii İşverenleri Sendikası, Çalışma Mevzuatı Seminer Notları, Antalya, 26-30 Eylül 2012, 27, 29; Sümer (n 7) 11; Efe Yamakoğlu, Isşverenin Isşyeri Hekimi ve İş Güvenliği Uzmanı Çalıştırma Yükümlülügüu, (Seçkin 2016) 21; Seda Arslan, 'İş Sağlığı ve Güvenliği Kanunu'na Göre İşverenin Genel Yükümlülükleri' (2014) 20(1) MÜHFHAD, Özel Sayı, Prof. Dr. Ali Rıza Okur'a Armağan, 767, 807.

31 Çelik, Caniklioğlu and Canbolat, (n 30$) 373$ vd.; Süzek (n 10) 412; Ömer Ekmekçi, 4857 Sayll İş Kanunu'na Göre İş Sağlığı ve Güvenliği Konusunda Issyeri Örgütlenmesi, (Legal 2005) 39 vd.; Caniklioğlu, ‘İșveren Yükümlülükleri’ (n 30) 36; Özdemir (n 10) 65 vd.; Yamakoğlu (n 30) 49; Arslan ( n 30) 776 vd; Zehra Gizem Ateş, 'COVID-19'un İşverenin İş Sağlı̆̆ ve Güvenliği Konusunda Alması Gereken Önlemlere Etkisi’, (2020) 19(38) İstanbul Ticaret Üniversitesi Sosyal Bilimler Dergisi, COVID-19 Hukuk Özel Sayısı, 161, 166.

32 Akın, 'COVID-19'un İș İlişkilerine Etkileri' (n 7) 18.

$33<$ https://www.ailevecalisma.gov.tr/media/40969/isyerlerinde-koronaviruse-covid-19-karsi-alinmasi-gereken-onlemler. pdf $>$ Erişim Tarihi 14 June 2020.
} 
işyeri özelindeki tehlikeler belirlenerek ayrı bir risk değerlendirmesi veya mevcut risk değerlendirmesi üzerinde güncelleme yapılması gerekmektedir. Çalı̧anların işe başlamadan önce temassız ateş ölçerle kontrol edilmesi ve ateşi olanların işyeri hekimine yönlendirilmesi gerekir. İşyeri genelinde çalışanların sosyal mesafesini sağlamak için uygun bir çalışma modeli geliştirilmelidir. Çalışanlar, işyeri ortamına girmeden ve çalışma sırasında en az yirmi saniye boyunca sabun ve suyla ellerini yıkamaları konusunda bilgilendirilmelidir, su ve sabuna erişim olmadığı takdirde alkol bazlı bir el dezenfektanı kullanarak ellerini sık sık temizlemeleri sağlanmalıdır. Çalışanlara verilecek olan iş sağlığı ve güvenliği eğitimleri uzaktan eğitim şeklinde, işyeri temizliği ve düzeni, hijyen ve psikososyal risk faktörleri konuları öncelikli olarak verilmelidir. İşyeri belirli aralıklarla mümkünse doğal yolla havalandırılmalıdır. Bu ve buna benzer önlemlere işverenin uyup uymadığ 1 , işverenin sorumluluğunun tespitinde dikkate alınmalıdır. Yine TC Aile, Çalışma ve Sosyal Hizmetler Bakanlı̆̆ İş̧ Sağlığ ve Güvenliği Genel Müdürlüğü tarafından "Yeni Koronavirüs Salgını ile Mücadele Kapsamında İş Sağlı̆̆ ve Güvenliği Yönünden Sıkça Sorulan Sorular ve Cevapları" kitapçığı yayınlanarak işverenlere yol gösterici tavsiyelerde bulunulmuştur ${ }^{34}$.

TC Sağlık Bakanlığı Bilim Danışma Kurulu tarafindan "COVID-19 Salgın Yönetimi ve Çalışma Rehberi” yayınlanmış ve farklı iş kollarına yönelik olarak alınması gereken önlemler ayrıntılı olarak belirtilmiştiri ${ }^{35}$. Örneğin AVM ve AVM içindeki işyerlerinde, bakkallarda, kasaplarda, kuyumcu, Pazar yerleri, terzi, kent içi ulaşım araçlarında, madenlerde, akaryakıt istasyonlarında, restoran, lokanta vb yemeiçme sunan işletmelerde, spor salonlarında alınması gereken önlemler, işyerlerine, müşterilere, personeli korumaya yönelik olarak ayrıntılı bir şekilde açılanmıştır. İşveren, Aile, Çalışma ve Sosyal Hizmetler Bakanlığının, Sağlık Bakanlığının, Bilim Kurulunun tavsiyelerini, onların yayınladığı rehberleri ve çalışmaları takip etmekle ve kendi işyeri için tavsiye edilen önlemleri almakla yükümlüdür ${ }^{36}$.

İşveren, işçinin sağlığını tehdit eden salgının işyerinde bulaşma ihtimalini ortadan kaldırmak için işyerini tamamıyla kapatabilir. Bu durumda işçiler işyerinde söz konusu virüsün bulaşma riskine maruz bırakılmadıkları için, olası enfekte olmaları durumunda, hastalık ile iş arasında uygun illiyet bağının kurulması engellenmiş olacaktı $^{37}$. Bilim Kurulunun önerilerine, uyarılarına rağmen hala işyerinde işçi çalıştırmaya devam ettiren her işverenin kusurlu sayılması gerektiği ifade edilmiştir ${ }^{38}$. Ancak işyerinde faaliyetine devam eden her işvereni mutlak kusurlu kabul etmemek

\footnotetext{
$4<$ https://drive.google.com/file/d/1wyqKwK18db87PkEtfBO4FgrHBM9FY3tt/view> Erişim Tarihi 26 June 2020.

$35<$ https://covid19bilgi.saglik.gov.tr/depo/toplumda-salgin-yonetimi/salgin-yonetimi-ve-calisma-rehberi/COVID-19 SALGIN_YONETIMI_VE_CALISMA_REHBERI.pdf> Erişim Tarihi 26 June 2020.

36 Ateş (n 31) 166.

37 Akın, 'COVID-19'un İş İlişkilerine Etkileri' (n 7) 18.

38 Söz konusu görüşe göre, COVID-19'un iş kazası sayılması bakımından fiili karine olmalıdır. COVID-19'un işyerinde bulaşma ihtimali yüksektir ve aksinin ispatı işverende olmalıdır, Murat Özveri, 'Pandemi Sürecinin İş Hukukuna Yansımaları', (2020) İzmir Barosu Bülten, İş ve Sosyal Güvenlik Hukuku Komisyonu Pandemi Özel Bülteni, 25, 35.
} 
gerekir. İşveren, gözetme borcunun gereğini yerine getirerek her türlü önlemi almış ve üretimine/hizmetine devam etmiş olabilir. İşveren, işletmesel karar gereği tercih hakkına sahiptir. İşyerinde üretimi/hizmeti sürdürmeyi seçiyor ise virüsün bulaşma ihtimalini en aza indirecek/yok edecek önlemler alması gerekir. İşveren, COVID-19 virüsünün kaçınılmaz olduğunu veya mücbir sebep oluşturduğunu ileri sürerek iş sağlığı ve güvenliği yükümlülüklerini yerine getirmekten kaçınamaz ve sorumluluktan kurtulamaz ${ }^{39}$.

\section{B. COVID-19'daki Anilik Unsuru}

Bir kazanın söz konusu olabilmesi için yukarıda ifade edildiği üzere zarar doğuran olayın aniden veya çok kısa bir zaman içinde ortaya çıkması gerekir. Anilik, olayın bir anda değil, bütün olarak bir kerede doğmasını ifade etmektedir ${ }^{40}$. Ani olayın gerçekleşmesinden sonraki bir zamanda sigortalıda bedenen veya ruhen zararlar meydana gelebilmektedir.

COVID-19 hastalığının belirtilerine bakıldığında en çok karşılaşılan belirtilerin ateş, öksürük ve nefes darlığı olduğu ifade edilmiştir. Belirtisiz olgular olabileceği bildirilmekle birlikte, bunların oranı da bilinmemektedir. Şiddetli olgularda zatürre, ağır solunum yetmezliği, böbrek yetmezliği ve ölüm gelişebilmektedir. Korona virüsün kuluçka süresi ise 2 gün ile 14 gün arasında değişmektedir ${ }^{41}$. Dolayısıyla zarar doğuran olayın kısa bir zaman içinde ortaya çıkmasından dolayı bir kazada aranan anilik unsuru COVID-19'da gerçekleşmiştir diyebiliriz. Zira virüs ile enfekte olmadan kısa bir zaman sonra sigortalıda bedenen zarar meydana gelmektedir.

Yargitay 21. Hukuk Dairesinin emsal olabilecek 15.04.2019 tarihli kararında H1N1 virüsünün (domuz gribi) bulaşması sonucu vefat eden işçinin ölümünün iş kazas1 olduğu belirtilmiştir ${ }^{42}$. H1N1 virüsünün kuluçka süresinin 1-4 gün arasında değiştiği raporda bildirilmiştir. İş kazası ani bir olay şeklinde ortaya çıkabilir ve buna bağlı olarak zarar derhal gerçekleşebilir. Bununla birlikte gazdan zehirlenme olayında olduğu gibi olayın etkileri daha sonra da ortaya çıkabilir. Yargıtay böyle bir durumda sonradan oluşan zarar ile olay arasında uygun illiyet bağı bulunması koşuluyla olayın iş kazası kabul edilmesi gerektiğini belirtmiştir. Söz konusu kararda 1-4 gün arasında değiş̧en kuluçka süresi, kazadaki anilik unsurunu karşılamaktadır. Korona virüsün kuluçka süresinin 2 ila 14 gün arasında gerçekleştiği göz önüne alındığında içtihatta belirtilen yaklaşıma paralel olarak COVID-19'a yakalanma olayının da kaza sayılması mümkündür. Zira söz konusu Kararda da belirtildiği üzere, olayın etkilerinin bir süre devam ederek zaman içinde artması ve buna bağlı

\footnotetext{
Akın, 'COVID-19'un İş İlişkilerine Etkileri' (n 7) 18.

40 ibid 22.

$41<$ https://covid19bilgi.saglik.gov.tr/tr/sss/halka-yonelik.html > Erişim Tarihi 16 June 2020.

42 Yargitay $21 \mathrm{HD}, 5018 / 2931,15.04 .2019<$ www.kazanci.com>.
} 
olarak sonucun daha sonra gerçekleşmesi mümkündür. Öğretide domuz gribindeki 1-4 günlük kuluçka süresinin Korona virüsteki 2-14 günlük kuluçka süresine göre daha kısa olduğu, Korona virüsteki kuluçka süresinin uzunluğunun illiyet bağının kurulmasını engelleyebileceği ifade edilmiştir ${ }^{43}$.

Yargıtayın H1N1 virüsüne bağlı olarak ölüm olayının gerçekleştiği olayı iş kazası sayması kararının isabetli olduğunu ve Korona virüsü bakımından da emsal teşkil etmesi gerektiği kanaatindeyiz ${ }^{44}$. Buna göre COVID-19 hastalığının işin görülmesi sırasında, iş ortamının koşullarından doğması halinde iş kazası sayılması gerekecektir. Öğretide baskın görüş, bunun bir iş kazası sayılması gerektiği şeklindedir ${ }^{45}$. İşçinin işyerinden kaynaklı bir COVID-19 virüsünü kapması ve buna bağlı olarak hastalanıp ölmesi halinde, olay iş kazası olarak değerlendirilecektir. Virüsün çalışan ve işyeri ile ilişkili olduğu ispatlanabildiği ölçüde COVID-19'dan kaynaklı zararları iş kazası saymak gerekecektir. COVID-19 hastalığında virüsün bulaşıp bulaşmadığının anında derhal belli olmaması, belirli bir kuluçka süresinin aranması ve buna bağlı olarak zararın sonradan ortaya çıkması iş kazası olarak nitelendirilmesinde ispat zorluğu yaratmaktadır. Önemli olan, virüsün işyeri ile ilgisini tespit edebilmektir. İşyeri ile ilgisi tespit edildiğinde, işçiyi hemen veya sonradan engelli hale getiren olay, sosyal güvenlik kurumu bakımından iş kazası sayılacaktır. İşverenin kusuru oranında da sorumluluğuna gitmek mümkündür.

\section{COVID-19'daki Dışsallık Unsuru}

Birkazanın borçlarhukuku ve iş hukuku bakımından kaza olarak nitelendirilebilmesi için, kazanın kişinin isteği dışında, dıştan gelen bir etkinin sonucu olarak ortaya çıkması gerekir. Ancak aynı durum, sosyal güvenlik hukuku bakımından kaza kavramında mutlak şart değildir. Sosyal güvenlik hukuku bakımından kaza kavramının kapsamına, dış etkenlerin dışında iç etkenlerin de alınması gerekebiliir ${ }^{46}$. Dolayısıyla bir olayın iş kazası sayılabilmesi için mutlaka dıştan gelen bir etkinin varlığı şart değildir. Zira 5510 sayılı Kanun $\mathrm{m}$. 13'te iş kazasının unsurlarına yer verilirken dıştan gelen bir etkinin varlığından bahsedilmemiştir. Bu durum pek tabi olayın sosyal güvenlik hukuku bakımından iş kazası sayılması içindir. İşverenin sorumluluğu için kusurunun bulunması şart olup nedensellik bağının varllğı için sigortalının yaptığı iş ile gerçekleşen kaza arasında bir bağ olması gerekmektedir. Korona virüs de diştan gelen bir sebeptir. İşçide hemen veya sonradan bir zarar

\footnotetext{
43 Nurşen Caniklioğlu, Koronavirüs Döneminde Güncel Hukuki Meseleler Sempozyumu, İbn Haldun Üniversitesi, 29.05.2020, <https://www.youtube.com/watch?v=sQPmdcI-G4c> Erişim Tarihi 10 June 2020.

${ }^{4}$ Akın, 'COVID-19'un İş İlişkilerine Etkileri' (n 7) 24.

${ }^{45}$ Akın, 'COVID-19'un İș İlișkilerine Etkileri' (n 7) 24; Hakan Keser, 'Korona Virüs (Covid 19) Özelinde Bir Salgın Durumunda İş Mevzuatı Kapsamında İşçi ve İşverenin Kullanabileceği İzin, Esnek Çalışma Süreleri ve Fesih Hakları Üzerine Bir Değerlendirme' (2020) 17(65) Legal İSGHD, 23, 70; Yürekli (n 6) 45; Özveri, (n 38) 27-28; Mehmet Zahid Yener, 'COVID-19 Salgınının İş Kazası ve Meslek Hastalığı Bakımından Değerlendirilmesi' (2020) Koronavirüs Döneminde Güncel Hukuki Meseleler Sempozyumu Bildiri Özeti Kitabı, İbn Haldun Üniversitesi Yayınları, 108, 110.

46 Sözer (n 6) 336; Okur (n 6) 326.
} 
bırakabilir. COVID-19 hastalığı, işçinin iradesinden bağımsız, dışsal bir etkinin sonucu olarak meydana geldiği için dişsallık unsurunu taşımaktadır ${ }^{47}$.

Yargıtay 10. Hukuk Dairesi ve 21. Hukuk Dairesi kararlarında sigortalının kalp krizi $^{48}$ veya beyin kanaması ${ }^{49}$ geçirmesi, iş kazası kapsamında değerlendirildiği gibi sigortalının intihar etmesi ${ }^{50}$ de iş kazası kapsamında değerlendirilmektedir. Yargıtay, sosyal güvenlik hukuku anlamında bir iş kazası sayılabilmesi için, isabetli bir yaklaşımla kalp krizi veya beyin kanaması olaylarında, etkinin mutlaka dıştan gelmesini aramıyor. Kalp krizi olaylarında etkinin içten mi ya da dıştan mı geldiğinin ispatı kolay olmamaktadır. Sigortalı, işyerinin koşullarından ya da kendi kalp rahatsızlığından dolayı kalp krizi geçirmiş olabilir. Sigortalının kalp krizi geçirmesi, sigortalının işyerinde bulunduğu sırada veya işveren tarafindan yürütülmekte olan iş dolayısıyla meydana geliyorsa iş kazası saymak için yeterli olacaktır. Bu sebeple geniş yorumlamak isabetli bir yaklaşımdır ${ }^{51}$. Bununla birlikte konu öğretide tartışmalı olup içten gelen olayların iş kazası olarak kabul edilemeyeceği de ileri sürülmektedir ${ }^{52}$. Yargıtayın sigortalının kalp krizi veya beyin kanaması geçirmesi halinde sosyal devlet ilkesi gereği geniş yorumladığı yaklaşımını COVID-19 özelinde de sürdüreceği kanaatini taşıyoruz. Zira Yargıtay Hukuk Genel Kurulu, 5510 sayılı Kanun madde 13 hükmünü sosyal güvenlik hukuku ilkeleri içinde değerlendirmekte, maddede yer alan herhangi bir hâle uygunluk varsa zararlandırıcı sigorta olayının kaynağının işçi olup olmaması ya da ortaya çıkmasındaki diğer etkenlerin değerlendirilmesinde dar bir yoruma gitmemektedir ${ }^{53}$.

\section{COVID-19 Özelinde Nedensellik Bağı}

\section{Genel Olarak}

Sosyal güvenlik hukuku bakımından iş kazasının varlığı için kaza ile zarar arasında uygun nedensellik bağının olması gerekli ve yeterli iken iş hukuku bakımından iş kazasından işverenin sorumlu olabilmesi için kaza ile zarar arasındaki nedensellik

\footnotetext{
47 Talat Canbolat and Hasan Kayırgan, 'Korona Virüs Salgınının İş Sözleşmesi ile İşçi İşveren İlişkilerine Etkisi ve Sonuçları', (2020) 5(1) Çankaya Üniversitesi Hukuk Fakültesi Dergisi Arş. Gör. Ceren Damar Şenel Armağanı, 637, 646.

48 Yargitay 10 HD, 1292/10164, 23.12.2019 <www.kazanci.com>; Yargitay Hukuk Genel Kurulu, 21-816/457, 16.04.2019 <www.kazanci.com>; Yargitay 21 HD, 2721/2084, 18.03.2019<www.kazanci.com>.

49 Yargitay $21 \mathrm{HD}, 7249 / 48,14.01 .2019<$ www.kazanci.com $>$.

50 Yargitay $21 \mathrm{HD}, 5063 / 902,17.02 .2020<$ www.kazanci.com>.

51 "Daha açık ifadeyle; sigortalının, işyerinde çalışmakta iken kalp krizi geçirerek ölümü, 506 sayıl Sosyal Sigortalar Kanunu'nun 11. maddesinin ( A ) fikrasının (a) bendinde gösterilen "'Sigortalının işyerinde bulunduğu sirada meydana gelme"” haline uygun bir olay olduğu gibi, ayn maddenin ( $b$ ) bendinde yer alan "”işveren tarafindan yürütülmekte olan iș dolaylslyla meydana gelme"” haline de uygun olup; iş kazası sayllması gerekir. Maddede, başkaca bir șart ya da kusitlamaya yer verilmemiş olduğundan, yasada olmayan bir kisitlamanın yorum yoluyla getirilmesine de olanak yoktur.", Yargitay Hukuk Genel Kurulu, 21-529/527, 13.10.2004 <www.kazanci.com>.

52 Kișinin bedeni yapısının arızalı olmasından kaynaklanan zarar varsa iș kazası olarak kabul edilemeyeceği yönünde bkz, Caniklioğlu 'Değerlendirme 2002' (n 6), s. 343; Tuncay and Ekmekçi (n 6) 395, 405.

53 Yargitay Hukuk Genel Kurulu, 21-816/457, 16.04.2019, <www.kazanci.com>; Yargitay Hukuk Genel Kurulu, 21-400/432, 14.10.2009<www.kazanci.com>.
} 
bağının yanında kaza ile yapılan iş arasında uygun nedensellik bağının varlığı da gerekmektedir $^{54}$. Nihayetinde yapılan iş ile zarar arasında da nedensellik bağı gerekecektir. COVID-19 bakımından konuya yaklaşılırsa, işverenin sorumluluğunun tespiti için, Korona virüsü ile enfekte olan bir işçinin bu durumunun yapılan işten kaynaklanması gerekir. Korona virüsüne yakalanma ile işçinin yaptığı iş arasında nedensellik bağının olması gerekir. Örneğin eğer işçi, işyerine toplu taşıma ile gidiyor ve toplu taşıma ile işyerine giderken virüs ile enfekte olmuş ise bu da tespit ve ispat edilebiliyorsa işverenin sorumluluğuna gidilmemesi gerekir. Diğer taraftan işverenin sağladığı bir servis aracıyla işin yapıldığı yere gidiş gelişi sırasında, virüsün bulaşmış olduğu tespit edilebiliyorsa, iş kazası sayılacaktır.

İşverenin sorumlu olabilmesi için, işçinin COVID-19 hastalı̆̆ına yakalanmasında işverenin kusurlu olması gerekir. COVID-19 özelinde nedensellik bağının tespiti, oldukça zordur. Zira hızlı bulaşma ihtimali olan virüsün işyeri ortamından $\mathrm{m}$ işyeri dışından mı bulaştı̆ıının ispatı kolay değildir. Ancak işverenin gerekli önlemleri alıp almadığı, filyasyon çalışmaları gibi bazı durumlar nedensellik bağının tespitinde yardımcı olabilir. İşveren, iş sağlığı ve güvenliği yükümlülüklerine uymamışsa ve iş kazası da işverenin yükümlülüklerini yerine getirmemesinden kaynaklanmışsa, işveren oluşan zararlardan sorumlu olacaktır. Yargıtaya göre işverenin kusurlu eylemi ile zarar arasında uygun bir nedensellik bağı yoksa işverenin sorumluluğundan da söz edilemeyecektir ${ }^{55}$.

\section{Nedensellik Bağını Kesen Nedenler}

İşverenin sorumluluğu, yapılan iş ile kaza arasındaki nedensellik bağının kesildiği durumlarda ortadan kalkar. Uygun nedensellik bağını kesen nedenler; kazaya uğrayan işçinin ağır kusuru, üçüncü kişinin ağır kusuru ve zorlayıcı nedendir ${ }^{56}$. Yargıtaya göre de illiyet bağının mücbir sebep, zarar görenin veya üçüncü kişinin ağır kusuru nedenleriyle kesilmesi halinde işverenin sorumluluğuna gidilmesi mümkün değildir ${ }^{57}$. Bunun için işçinin eyleminin iş ile kaza arasındaki uygun nedensellik bağını ikinci plana itebilecek yoğunluğa ulaşması gerekir ${ }^{58}$. Eğer işçinin kusuru nedensellik bağını kesecek ağırlıkta değilse, birlikte (müterafik) kusur söz konusu olur ve işverenin ödeyeceği tazminattan indirim yapılır ${ }^{59}$. Yine aynı şekilde uyarılara

\footnotetext{
Sözer (n 6) 338; Sümer (n 7) 98, 208; Akın, ‘COVID-19’un İş İlişkilerine Etkileri' (n 7) 27; Yürekli (n 6) 45.

55 Yargitay Hukuk Genel Kurulu, 21-1121/386, 20.03.2013, <www.kazanci.com>.

56 Fikret Eren, Borçlar Hukuku Genel Hükümler (21th edition, Yetkin, 2017) 579; Fikret Eren, Sorumluluk Hukuku Açısından Uygun İlliyet Bağı Teorisi, (Ankara Üniversitesi Hukuk Fakültesi Yayınları No:361 1975) 174-175; Çelik, Caniklioğlu and Canbolat (n 30) 401, 403; Özdemir (n 10) 522; Sümer (n 7) 211; Yürekli (n 6) 46.

${ }_{57}$ "Kusurlu olmadı ̆̆ halde işvereni, meydana gelen zarardan sorumlu tutmak adalet ve hakkaniyet duygularını incitir.", Yargitay Hukuk Genel Kurulu, 21-1121/386, 20.03.2013, <www.kazanci.com>; Yargitay Hukuk Genel Kurulu, 21-586/95, 12.02.2014, <www.kazanci.com>.

58 Özdemir (n 10) 522.

59 Süzek (n 10) 427; Çelik, Caniklioğlu and Canbolat, (n 30) 402; Özdemir (n 10) 523; Sümer (n 7) 211; Akın 'Nedensellik Bağı' (n 10) 34
} 
rağmen COVID-19 tedbirlerine uymayan üçüncü bir kişinin ağır kusuru sonucu işçi ile teması halinde nedensellik bağının kesilebileceğinden bahsedilebilir ${ }^{60}$.

\section{Zorlayıcı Neden ve Kaçınılmazlık İlkesinin COVID-19'da Görünümü}

Zorlayıcı nedenin ne olduğu konusunda Sosyal Sigortalar ve Genel Sağlık Sigortası Kanununda ve İş Kanununda bir tanım yoktur. Zorlayıcı neden kavramına ilişkin olarak Kısa Çalışma ve Kısa Çalışma Ödeneği Hakkında Yönetmelikte ${ }^{61}$ bir tanım yapılmıştır. Söz konusu Yönetmelik m. 3/1-(h)’ye göre; “zorlayıcı sebep: Işsverenin kendi sevk ve idaresinden kaynaklanmayan, önceden kestirilemeyen, bunun sonucu olarak bertaraf edilmesine imkân bulunmayan, geçici olarak çalışma süresinin azaltılması veya faaliyetin tamamen veya kısmen durdurulması ile sonuçlanan dişsal etkilerden kaynaklanan dönemsel durumları ya da deprem, yangın, su baskın, heyelan, salgın hastalı, seferberlik gibi durumlarl" ifade eder. Zorlayıcı neden, genel bir davranış normunun veya borcun ihlaline mutlak ve kaçınılmaz bir şekilde yol açan öngörülemez, karşı konulamaz ve dışarıdan gelen olağanüstü bir olay olarak tanımlanabilir ${ }^{62}$. Buna göre zorlayıcı neden, çoğunlukla yıldırım düşmesi, kasırga, deprem, sel gibi bir doğa olayı olabileceği gibi bazen savaş, genel grev, askeri darbe gibi beşeri ya da sosyal bir olay, hatta ithal yasağı, kamulaştırma gibi hukuki bir olay da olabilir ${ }^{63}$.

Yargıtaya göre; "Mücbir sebepte öngörülemezlik ve kaçınılmazlık objektif yani herkes için geçerli olup, mutlak bir anlam taşır. Kaçınılmazlı̆̆ın mutlaklığından amaç, teknik ve bilimin o andaki verilerine göre mevcut her türlü önlem alınsa, her türlü özen gösterilse bile ihlalin, dolayısıyla zararlı sonucun hiç kimse tarafindan önlenememesidir.64" İfade edilmelidir ki mücbir sebep olarak nitelendirilen her olay mutlak nitelikte olmayabilir. Her olay, oluş şekline, olayın meydana geldiği yere göre farklı değerlendirilebilir ${ }^{65}$.

COVID-19 özelinde konuya yaklaşıldığında salgın hastalığın mücbir sebep oluşturup oluşturmadığı incelenmelidir. Mücbir sebebin en önemli özelliği öngörülemez olmasıdır. İşveren, her türlü önlemi almasına rağmen, işyeri dışından öngörülemeyen bir sebebin ortaya çıkması gerekir. Korona virüsünün öngörülebilir olması, onu mücbir sebep olarak değerlendirilmesi görüşünden uzaklaştırmaktadır.

60 Akın, 'COVID-19'un İș İlişkilerine Etkileri' (n 7) 30.

${ }^{61}$ Kısa Çalışma ve Kısa Çalışma Ödeneği Hakkında Yönetmelik, RG 30.04.2011/27920.

62 Eren, Borçlar Genel (n 56) 579; Can Tuncay, 'Kurumun İşverene Rücuu-Olayda Kaçınılmazlık Durumu’ (Aralık 2006)(4) Sicil IHDD 183, 187; Canbolat and Kayırgan (n 47) 639.

63 Eren, Borçlar Genel (n 56) 580; Eren (n 56) 177; Tuncay (n 62) 187; Sümer (n 7) 213; Yargitay Hukuk Genel Kurulu, 102682/986, 01.10.2019 <www.kazanci.com>; Yargitay Hukuk Genel Kurulu, 10-1141/282, 27.02.2013, <www.kazanci.com>.

64 Yargitay Hukuk Genel Kurulu, 10-1141/282, 27.02.2013 <www.kazanci.com>.

65 Eren (n 56) 178; Akın, 'COVID-19'un İș İlişkilerine Etkileri' (n 7) 30; “Mücbir sebepte önlenememe (kaçınılmazlık) mutlaktır ve kaçınılmazlığa sebep olan unsur tazminat borçlusunun riziko alanı dışında gerçekleşir. Buna karşılık beklenmeyen hale sebep olan kaçınılmazlık, borçlunun riziko alanından kaynaklanır, dolayısılla aslında önlenemezlik (kaçınamama) sadece borçlu açısından söz konusudur; mutlak değil, nispidir”, Gaye Baycık, 'Sosyal Güvenlik Kurumunun İş Kazası veya Meslek Hastalığından Kaynaklanan Rücu Davalarına Eleştirel Bakış’ (2017) 7(1) Sosyal Güvenlik Dergisi, 31, 57. 
Bu noktada kaçınılmazlık ilkesi, zorlayıcı neden ile birlikte incelenmelidir. Zira kaçınılmazlık, uygun nedensellik bağını kesen sebeplerden en önemli olanı olup zorlayıcı nedenin bir unsurudur ${ }^{66}$. Öngörülebilir bir olay olmasına rağmen beklenilmeyen hal olarak kaçınılmazlık söz konusu olabilir.

Kaçınılmazlık ilkesinin tanımı 5510 sayılı Kanunda yapılmamıştır. Ancak Kanunda işverenin sorumluluğunun tespitinde kaçınılmazlık ilkesinin dikkate alınacağ belirtilmiştir. (5510 sayılı Kanun madde 21/I, madde 76/IV). Kaçınılmazlık ilkesinin tanımı Sosyal Sigorta İşlemleri Yönetmeliği madde 45/3’te düzenlenmiştir. Yönetmelikte işverenin sorumluluğunun tespitinde kaçınılmazlık ilkesinin dikkate alınacağ 1 belirtildikten sonra kaçınılmazlık, "olayın meydana geldiği tarihte geçerli bilimsel ve teknik kurallar gereğince alınacak tüm önlemlere răgmen, iş kazasl veya meslek hastalığının meydana gelmesi durumu” olarak tanımlanmıştır. İşveren, alınması gerekli herhangi bir önlemi almamış ise olayın kaçınılmazlığından söz edilemeyecektir. Yargıtay da kaçınılmazlığ veya ne kadar özen gösterirse göstersin, hangi tedbir alınırsa alınsın oluşması engellenemeyen bir durum" olarak ifade etmiştir. İşverenin mevzuatta yer almasa bile, iş sağlı̆̆ ve güvenliği yönünden aklın, bilimin, tekniğin gerekli gördüğü her türlü önlemi almak zorunda olduğu, Yargıtayın yerleşik içtihatlarındandır. Alınması gereken her türlü önlem, objektif olarak işverenden beklenen makul önlemler olmalıdır. Yargıtay devamla, hastalığın ortaya çıkmasında kaçınılmazlığın varlığ1 halinde işveren ve üçüncü kişilerin, belirlenen kaçınılmazlık oranında sorumluluktan kurtulacağını da belirtmektedir ${ }^{67}$.

Yargıtaya göre iş kazasının meydana gelmesinde tamamen kaçınılmazlığın etkili olduğu durumlarda, hâkim tarafından TBK madde 51 çerçevesinde tazminat belirlenirken hakkaniyet ilkeleri gözetilerek işverenin \%60, işçinin ise $\% 40$ kusurlu olduğunun kabulü gerekmektedir. İş kazasının tamamen kaçınılmazlıktan kaynaklandığı durumlarda kaçınılmazlığın yükünü taraflardan sadece birisine yüklemek, adalet duygusunu zedelemektedir. Kaçınılmazlık, her iki taraf açısından da önlenemez bir olay olduğuna göre, beklenmeyen olayın neden olduğu olumsuz sonuçlara her iki taraf da katlanmalıdır. Bu sebeple Yargıtaya göre kaçınılmazlığın etki ettiği zarar, hakkaniyetin gerektirdiği ölçüde taraflara yüklenmelidir. Yargıtay, olayın kaçınılmazlıktan kaynaklanması hâlinde sorumluluğun işçi ve işveren arasında $\% 50$ 'şer oranında paylaştırılması uygun gibi görünebilirse de, "işşinin işverene karşı daha güçsüz oluşu, nimet - külfet dengesi, işçiyi koruma ve sosyal devlet ilkesi" gibi nedenler karşısında işverene daha fazla sorumluluk verilmesinin hakkaniyet gereği olduğunu belirtmektedir. Dolayısıyla Yargıtay uygulamalarında kaçınılmazlık

\footnotetext{
66 Eren, Borçlar Genel (n 56) 582; Eren (n 56) 181; Canbolat and Kayırgan (n 47) 643; Yargıtay 10 HD, 5151/164, 15.01.2020 <www.kazanci.com>; Yargitay 10 HD, 7385/58, 13.01.2020 <www.kazanci.com>; Yargitay Hukuk Genel Kurulu, 101141/282, 27.02.2013<www.kazanci.com>.

67 Yargitay $10 \mathrm{HD}, 5151 / 164,15.01 .2020<$ www.kazanci.com>.
} 
durumunda sorumluluğun paylaştırılması kural olarak \%60 işveren, \%40 kazalı kusuru olarak sorumluluğun paylaştırılması şeklinde olmaktadır ${ }^{68}$.

COVID-19 bağlamında işçinin enfekte olması ve bunun sonucunda bir zarar görmesi, kaçınılmazlık kapsamında değerlendirilebilir ${ }^{69}$. Bunoktada korana virüs salgını, zorlayıcı neden olarak kabul edilebilir ${ }^{70}$. İşveren alması gereken tüm önlemleri aldıysa işverenin sorumluluğuna gidilirken kaçınılmazlık ilkesi göz önünde bulundurulabilir. Ancak salgının başladığı ilk dönemdeki etkisi ile normalleşme sürecinin yaşandığı sonraki dönemin etkisi birbirinden farklıdır ve kaçınılmazlık ilkesinin değerlendirilmesinde aradaki zaman ilişkisi de göz önünde bulundurulmalıdır ${ }^{71}$. COVID-19 hastalığın tedavisi için çare bulunmuş olabilir veya yayılmasının önüne geçilmiş olabilir. $\mathrm{Bu}$ durumda "kaçınılmazlık" da zamanla azalacaktır.

\section{Filyasyon Çalışmalarının Nedensellik Bağına Katkısı}

Filyasyon, bulaşıcı hastalık varlığında, hastalığı taşıyan kişinin temas ettiği herkesin o hastalık açısından taranmasıdır ${ }^{72}$. Filyasyon çalışmaları ile amaçlanan, etkeni ve kaynağı erken dönemde saptayarak hastalığın yayılmasını engellemektir. Filyasyon çalışmaları işverenin sorumluluğunun doğması bakımından nedensellik bağının tespitine yardımcı olabilir. Şöyle ki COVID-19 tanısı konan bir işçinin filyasyon çalışmaları sonucunda temas ettiği kişiler arasında iş arkadaşlarından kimsenin olmaması, zarar ile iş arasındaki nedensellik bağının kurulmasını engelleyebilir. Yine aynı şekilde COVID-19 tanısı konan bir işçinin filyasyon çalışmalarında iş arkadaşları ile teması saptanıyor ise, nedensellik bağının varlığı söz konusu olabilecektir ${ }^{73}$. Filyasyon raporlarında işyerinde çalışan bir işçinin COVID-19 ile enfekte olmasının saptanmasına rağmen işveren aynı işyerinde gerekli önlemleri almıyorsa kusuru söz konusu olacaktır ve böyle bir durumda işverenin kusurunun tespiti daha kolay olabilir. İşyerinde hiç vaka tespit edilmemiş de olabilir, ancak bir işçinin yakını Korona virüsüne yakalanmışsa, işveren gerekli önlemleri alarak o işçinin işyerine gitmemesini sağlamalıdır. Bu noktada işveren, işçinin enfeksiyon riski olan yerlere gidip gitmediğini ve yakınında COVID-19 hastasının olup olmadığını sorma hakkına sahiptir.

\footnotetext{
68 Yargitay Hukuk Genel Kurulu, 21-983/252, 07.03.2019, <www.kazanci.com>; Yargitay 21 HD, 5246/975, 20.02.2020, <www.kazanci.com>; Yargitay 21 HD, 6023/10373, 21.06.2016 <www.kazanci.com>.

69 Akın, 'COVID-19'un İş İlişkilerine Etkileri' (n 7) 31; Yener (n 45) 110; Aksi görüşe göre, Bilimsel ve teknik kararlar gereğince alınacak önlemlerin bulunduğu ve hangi önlemlerin alınması gerektiği hususunda kişiler uyarıldığı için kaçınılmazlık ilkesi söz konusu olmaz, Mehmet Bulut, 'Türkiye'de Pandemi Sürecinde İş Sağlığı ve Güvenliği Mevzuatına İlişkin Meseleler' (2020), Koronavirüs Döneminde Güncel Hukuki Meseleler Sempozyumu Bildiri Özeti Kitabı, İbn Haldun Üniversitesi Yayınları, 99, 100

70 Canbolat and Kayırgan (n 47) 646.

71 Akın, 'COVID-19’un İș İlişkilerine Etkileri' (n 7) 32.

$72<$ https://covid19bilgi.saglik.gov.tr/tr/> Erişim Tarihi 22 June 2020.

73 Akın, 'COVID-19'un İş İlişsilerine Etkileri' (n 7) 29-30.
} 
Filyasyon raporları sayesinde, işçiye virüsün kimden bulaştı̆̆1 tespit edilebilir. İşçiye ailesinden veya yakınlarından Korona virüsün bulaştığı tespit edildiğinde, bu durum iş kazası olarak değerlendirilemeyecektir. $\mathrm{Bu}$ sebeple filyasyon çalışmaları iş hukuku ve sosyal güvenlik hukuku bakımından da önem arz eder. Filyasyon raporlarının, Sosyal Güvenlik Kurumu ile paylaşılması durumunda, sorumluluğun tespiti noktasında ispat kolaylığı sağlayabilir ${ }^{74}$.

\section{E. İşverenin COVID-19 Vakasını Bildirmesi}

İşverenin iş kazalarını kazadan sonraki üç iş günü içinde Sosyal Güvenlik Kurumuna bildirme yükümlülüğü, 6331 sayılı Kanun madde 14'te düzenlenmişstir. Yine 5510 sayılı Kanun madde 13/II'de iş kazasının 4 üncü maddenin birinci fikrasının; (a) bendi ile 5 inci madde kapsamında bulunan sigortalılar bakımından bunları çalıştıran işveren tarafindan, o yer yetkili kolluk kuvvetlerine derhal ve Kuruma da en geç kazadan sonraki üç iş günü içinde, (b) bendi kapsamında bulunan sigortalı bakımından kendisi tarafından, bir ayı geçmemek şartıyla rahatsızlığının bildirim yapmaya engel olmadığı günden sonra üç iş günü içinde, iş kazası ve meslek hastalığı bildirgesi ile doğrudan ya da taahhütlü posta ile Kuruma bildirilmesinin zorunlu olduğu düzenlenmiştir. İşveren, iş kazasını bildirme yükümlülüğünü yerine getirmezse, 5510 sayılı Kanun madde 21 gereğince bildirim tarihine kadar geçen süre için sigortalıya ödenecek geçici iş göremezlik ödeneği, Kurumca işverenden tahsil edilecektir. İşverenin kusurlu olup olmadığına bakılmaksızın bildirim yükümlülüğüne aykırılı̆̆ın sonucu düzenlenmiştir.

Sosyal Güvenlik Kurumu genelgesinde her ne kadar COVID-19 vakalarının hastalık kapsamında bildirilmesi gerektiği ileri sürülmüş ise de işverenlerin bunu iş kazası olarak bildirmeleri gerektiği kanaatindeyiz ${ }^{75}$. Balcı'ya göre, COVID-19 hastalı̆̆ının iş kazası olup olmadığı tartışmalı olduğu için işveren, COVID-19 vakasını Genelge'ye dayanarak hastalık kapsamında da bildirse, geçici iş göremezlik ödeneğinden sorumlu olmamalıdır ${ }^{76}$. Ancak işverenin kusuru varsa, şüphesiz ki sorumluluğu doğacaktır.

Bulut (n 69) 101.

5 Yürekli (n 6) 48.

76 Mesut Balcı, 'Covit-19'un İş Güvenliği Yönünden Hukuki Nitelendirmesi’, Türkiye Barolar Birliği Eğitim Merkezi Online Eğitim Programları, TBB TV, 29 Nisan 2020, <https://www.youtube.com/watch?v=RwHqOMwMqq8>, Erişim Tarihi 7 June 2020. 


\section{Meslek Hastalığı Kavramı}

\section{A. Genel Olarak}

Meslek hastalığı kavramı 5510 sayılı Kanun madde 14/I'de tanımlanmıştır. Buna göre; "Meslek hastalı̆̆l, sigortalının çalıştığl veya yaptığı işin niteliğinden dolayı tekrarlanan bir sebeple veya işin yürütüm şartlarl yüzünden uğradiğl geçici veya sürekli hastallk, bedensel veya ruhsal engellilik halleridir". 6331 say1l Kanunda da meslek hastalığı, "mesleki risklere maruziyet sonucu ortaya çıkan hastalık" biçiminde tanımlanmıştır.

Meslek hastalığının iş kazasından farkı, tekrarlanan bir sebeple çalışanın yapmış olduğu işin koşullarından ve bu koşullara maruz kalma nedeniyle ortaya çıkmasıdır. Dolayısıyla iş kazası, aniden veya kısa bir zaman diliminde; meslek hastalığ uzun bir zaman diliminde ortaya çıkmaktadır ${ }^{77}$. Ortaya çıkış nedenleri farklı olan "iş kazası" ve "meslek hastalı̆̆ı", iki ayrı risk olarak kapsama alınmıştır ve söz konusu her iki risk grubu farklı özelliklere sahiptir. Bir hastalığın meslek hastalığı olarak tespit edilebilmesi için aşağıdaki unsurlara sahip olması gerekir.

\section{B. Meslek Hastalığının Unsurları}

\section{Sigortalı Olma}

5510 sayılı Kanunda meslek hastalığının tanımı verilirken "sigortalının" çalıştığı veya yaptığı işin niteliğinden dolayı tekrarlanan bir sebeple veya işin yürütüm şartları yüzünden uğradığ meslek hastalığı olarak ifade edilmiştir. Bu durumda bir kişinin meslek hastalığı sigortasından yararlanabilmesi için her şeyden önce sigortalı olması gerekmektedir. İş kazası bakımından sigortalı sayılan kişiler ile meslek hastalığı bakımından sigortalı sayılan kişiler örtüşmektedir. İş kazası kavramının unsurları incelenirken kimlerin sigortalı sayılacağı ele alınmışt ${ }^{78}$. Aynı bilgiler meslek hastalığı bakımından da geçerli olduğu için tekrara düşmemek adına yukarıdaki bilgilere atıf yapmakla yetinilmiştir.

\section{2. İşin Niteliği veya Yürütüm Şartlarına Bağlı Olarak Geçici veya Sürekli Bir Hastalığın Ortaya Çıkması}

Meslek hastalığının unsurlarından bir diğeri, 5510 sayılı Kanun madde 14'te belirtildiği üzere hastalığın işin niteliği veya yürütüm şartlarına bağlı olarak ortaya çıkmasıdır. Dolayısıyla bir hastalığın meslek hastalığı olarak kabul edilebilmesi

\footnotetext{
7 Güzel, Okur and Caniklioğlu (n 6) 381 vd.; Tuncay and Ekmekçi (n 6) 417; Yürekli (n 6) 44-45; Sümer (n 7) 99; Ayşe Ledün Akdeniz, Meslek Hastalı̆̆l Kavramı Üzerine, (Beta 2015) s. 21.

78 Bkz., II. İş Kazası Kavramı, B. İş Kazasının Unsurları, 1. Sigortalı Olma.
} 
için her şeyden önce hastalık ile sigortalının yaptığı iş arasında nedensellik bağının bulunması gerekir ${ }^{79}$. "İşin niteliği ", çalışanın ifa etmekte olduğu görevle ilgilidir. "İşin yürütüm şartlarl" ise mevcut çalışma koşullarının özelliğinden kaynaklanmaktadır ${ }^{80}$. Meslek hastalığının tümüyle mesleki özellikler taşıması, onu iş kazasından ayırır. Zira iş kazasının yapılan iş ile ilgili bulunması zorunlu olmadığı halde, meslek hastalığının sigortalının yaptığı işin sonucunda ortaya çıkması gerekir ${ }^{81}$.

Hangi hastalığın işin niteliği veya yürütüm şartlarına bağlı olduğunun tespiti her somut olayın özellikleri dikkate alınarak belirlenmelidir ve tespiti zordur. Çalışma Gücü ve Meslekte Kazanma Gücü Kaybı Oranı Tespit İşlemleri Yönetmeliği ${ }^{82}$ (bundan sonra Güç Kaybı Yönetmeliği olarak anılacaktır) ile meslek hastalıkları bir liste halinde sayılmıştır. Güç Kaybı Yönetmeliği madde 17/1'e göre; hangi hastalıkların meslek hastalığı sayılacağı ve bu hastalıkların, işten fiilen ayrıldıktan en geç ne kadar zaman sonra meydana çıkması hâlinde sigortalının mesleğinden ileri geldiğinin kabul edileceği Meslek Hastalıkları Listesine (Ek-2) göre tespit ve tayin edilir. Söz konusu hükme göre, bir hastalığın meslek hastalığı olarak nitelendirilebilmesi için, kural olarak, Meslek Hastalıkları Listesinde yer alması ve yine bu listede belirtilen süre içinde ortaya çıkmış olması gerekir. Meslek Hastalıkları Listesine göre meslek hastalıkları beş grupta toplanmıştır (Güç Kaybı Yönetmeliği madde 18/1). Bunlar, A Grubu: Kimyasal maddelerle olan meslek hastalıkları, B Grubu: Meslekî cilt hastalıkları, C Grubu: Pnömokonyozlar ve diğer meslekî solunum sistemi hastalıkları, D Grubu: Meslek bulaşıcı hastalıklar, E Grubu: Fizik etkenlerle olan meslek hastalıklarıdır.

Meslek Hastalıkları Listesinde yer almayan bir hastalık hali de meslek hastalığı olarak değerlendirilebilir. Zira 5510 sayılı Kanun madde 14/son'a göre, Güç Kaybı Yönetmeliğinde belirlenmiş hastalıklar dışında herhangi bir hastalığın meslek hastalığı sayılıp sayılmaması hususunda çıabilecek uyuşmazlıklar, Sosyal Sigorta Yüksek Sağlık Kurulunca karara bağlanır. Buna göre listede yer almayan bir hastalığın, işin niteliği veya işin yürütüm şartları yüzünden ortaya çıktı̆̆1 sağl1k kurulu raporu ve dayanağı tıbbi belgeler ispatlanması halinde Yüksek Sağlık Kurulu kararı ile meslek hastalığı olarak kabul edilebilecektir.

Meslek hastalığı, sigortalı çalışırken ortaya çıkabileceği gibi, sigortalının işten ayrılmasından sonra da ortaya çıkabilir. Meslek hastalığı, işten ayrıldıktan sonra meydana çıkmış ve sigortalı olarak çalıştı̆̆ işten kaynaklanmış ise, sigortalının 5510 sayılı Kanunla sağlanan haklardan yararlanabilmesi için, eski işinden fiilen ayrılmasıyla hastalığın meydana çıkması arasında bu hastalık için Güç Kaybı

\footnotetext{
Güzel, Okur and Caniklioğlu (n 6) 383; Tuncay and Ekmekçi (n 6) 416-417; Sümer (n 7) 99; Akdeniz (n 77 ) 59 vd.

80 Sözer (n 6) 359.

81 Güzel, Okur and Caniklioğlu (n 6) 383.

82 Çalışma Gücü ve Meslekte Kazanma Gücü Kaybı Oranı Tespit İşlemleri Yönetmeliği, RG 11.10.2008/27021.
} 
Yönetmeliğinde belirtilen süreden daha uzun bir zamanın geçmemiş olması şarttır (5510 sayılı Kanun madde 14/III). Ancak sözü edilen yükümlülük süresi mutlak değildir. Herhangi bir meslek hastalığının klinik ve laboratuvar bulgularıla belirlendiği ve meslek hastalığına yol açan etkenin işyerindeki inceleme sonunda tespit edildiği hallerde, meslek hastalıkları listesindeki yükümlülük süresi aşılmış olsa bile, söz konusu hastalık Kurumun veya ilgilinin başvurusu üzerine Sosyal Sigorta Yüksek Sağlık Kurulunun onayı ile meslek hastalığı sayılabilir (5510 sayılı Kanun madde 14/III-son cümle).

\section{Bedensel veya Ruhsal Bir Zarara Uğrama}

Sigortalının meslek hastalığından yararlanabilmesi için, uğradığı meslek hastalığı sonucunda bedensel veya ruhsal bir zarara uğraması gerekir. Söz konusu hastalık hali geçici olabilir, sigortalı bütünüyle iyileşebilir ya da hastalık hali sürekli olabilir ve vücutta kalıcı hasara yol açabilir. Hastalık halinin geçici veya sürekli olması, meslek hastalığı olarak nitelendirilmesinde herhangi bir farklılığa yol açmayacaktır. İş kazasında olduğu gibi, meslek hastalığında da sigortalının uğradığı zarar bedensel olabileceği gibi ruhsal da olabilir.

\section{Meslek Hastalığı ile Zarar Arasında Nedensellik Bağının Bulunması}

Sigortalının yaptığı iş ile yakalandığı meslek hastalığı arasında uygun nedensellik bağının bulunması gerekir. Nedensellik bağının varlığı, Meslek Hastalıkları Listesi ile ortaya konulmaktadır. Zira hangi hastalıkların meslek hastalığ sayılacağı, Meslek Hastalıkları Listesi ile düzenlenmiş bulunmaktadır. Bu durumda sigortalının yakalandığı hastalık, Meslek Hastalıkları Listesinde yer alıyor ve çalışması ile bağı kurulmuş ise nedensellik bağının varlığını ispata gerek kalmayacaktır ${ }^{83}$.

\section{COVID-19’un Meslek Hastalığı Olarak Değerlendirilmesi}

\section{A. Genel Olarak}

Meslek hastalı̆̆ ortaya çıkmamakta, işin niteliğinden dolayı sürekli tekrarlanan bir sebeple veya yürütüm şartları yüzünden yavaş yavaş meydana gelmektedir. Sigortalı uzun süre aynı işi yapmakta, aynı şekilde çalışmakta, işin yürütümü ve niteliği nedeniyle belirli bir zaman sonra yaptığ iş̧en etkilenmekte ve meslek hastalığına tutulmaktadır ${ }^{84}$. COVID-19'un meslek hastalığı olarak değerlendirilmesinde sağlık çalışanlarını diğer çalışanlardan ayırarak konunun incelenmesinde fayda vardır. Zira Korona

\footnotetext{
Güzel, Okur and Caniklioğlu (n 6) 384; Sözer (n 6) 360; Akdeniz (n 77) 67.

${ }^{84}$ Yargıtay 10 HD, 5151/164, 15.01.2020<www.kazanci.com>, Erişim Tarihi 25 June 2020.
} 
virüsün sağlı çalışanları açısından meslekleri gereği bulaşma riski daha yüksektir. Bununla birlikte konu salgın hastalık olduğunda kişilerin çalıştıkları yerlere göre ayrılmamaları gerektiği ifade edilmektedir. Bu görüşe göre, sağlık çalışanlarının diğer çalışan grubuna göre riski daha fazla olduğu kabul edilebilir. Ancak kargo çalışanları, belediye otobüsü şoförleri gibi çalışanlar da en az sağlık çalışanları kadar risk altındadır. Zira kargo çalışanlarının, internet üzerinden satıştan dolayı iş yükleri daha da artmakta ve sürekli temas halinde olmaları dolayısıyla da virüsle temas riskleri artmaktadır. Bu sebeple sağlık çalışanı ayrımına girilmeden Korona virüsü ile enfekte olan işçilerin durumu meslek hastalığı değil fakat iş kazası kapsamında değerlendirilmelidir ${ }^{85}$.

COVID-19'un "iş kazası" veya "meslek hastalığı" olarak kabul edilmesi, aslında yararlanmaya ilişkin haklar konusunda bir fark yaratmamaktadır. Korona virüsüne maruz kalan kişiye veya yakınlarına Sosyal Güvenlik Kurumu tarafından bağlanması gereken geçici veya sürekli yardımlar yönünden veya işverenden talep edilebilecek maddi ve manevi tazminatlar yönünden de bir fark olmayacaktır. Zira 5510 say1lı Kanun sistematiğinde iş kazası ve meslek hastalığ 1 risklerine tek bir sigorta kolundan "İ̧ kazası ve meslek hastalığı" sigorta kolundan güvence sağlanmaktadır. Sigortalıya sağlanacak yardımlar bakımından bir farklılık olmayacağ için COVID19'un iş kazası veya meslek hastalığı olarak değerlendirilmesi, "akademik" düzeyde kalacaktır ${ }^{86}$. İş kazası ile meslek hastalığının örtüştügü durumlarda, işçi açısından takip etmesi daha kolay bir prosedür olduğu için nihai olarak iş kazasına öncelik vermek yararlı olacaktır ${ }^{87}$.

\section{B. Sağlık Çalışanları Bakımından Konunun Değerlendirilmesi}

Sağlık çalışanlarının ${ }^{88}$ korona virüsü ile karşılaşma ihtimalleri, diğer çalışan gruplarına kıyasla daha yüksek görünmektedir. Sağlık çalışanlarının COVID-19’a maruz kalan en yüksek riskli meslek grubu olduğu ifade edilebilir. Zira hastane ortamı, virüsün her an yayılarak sağlık çalışanlarına bulaşmasına olanak sağlamaktadır. Sağlık çalışanlarının enfekte olması halinde, bunun hastanede olma ihtimali, hastane dışında olma ihtimaline göre daha yüksektir ${ }^{89}$.

Yapılan çalışmalarda, çalışanların virüsle karşılaşma risklerine göre dört maruz kalım düzeyi tanımlanmıştır. Bu sınıflamaya göre sağlık çalışanları COVID-19

\footnotetext{
5 Balc1 (n 76).

86 'COVID-19 Pandemisi Günlerinde İș Kazası ve Meslek Hastalığı Rehberi’, İstanbul Tabip Odası Hukuk Bürosu, 25.04.2020, s. 1, <https://www.istabip.org.tr/site_icerik/2020/mayis/covid_19_is_kazasi_meslek_hastaligi.pdf>, Erişim Tarihi 25 June 2020.

87 Özveri, (n 38) 27-28.

88 Dünya Sağlık Örgütü'ne göre hekim, hemşire, diş hekimi, sağlık memuru, ebe, eczacı, biyolog, diyetisyen, veteriner, fizyoterapist vb. kişiler sağlık çalışanı kabul edilmektedir, bkz < https://www.who.int/hrh/statistics/Health_workers classification.pdf> Erişim Tarihi 25 June 2020.

89 Akın, ‘COVID-19’un İș İlișkilerine Etkileri’ (n 7) 25.
} 
maruz kalımı için en yüksek riskli meslek grubu kabul edilmiştir ${ }^{90}$. Sağlık sektörünün yanı sıra, turizm ve taşımacılık gibi sektörlerde çalışanlarda da riskin fazla olduğu gözlenmiştir. Bunlar arasında koruyucu hizmet meslekleri (polis memurları, sslah memurlar1, itfaiyeciler), ofis ve idari destek meslekleri (kuryeler ve haberciler, hasta servis temsilcileri), eğitim (okul öncesi ve kreşler), toplum ve sosyal hizmet meslekleri (sağlık çalışanları, sosyal hizmet uzmanları, danışmanlar) ve inşaat sektörü (tesisatçılar, foseptik tesisatçıları, asansör onarımı işçileri) mevcuttur ${ }^{91}$.

Öğretide bir görüşe göre; bir hastalığın meslek hastalığg sayılabilmesi için, yapılan işin niteliğinden kaynaklanan bir sonucun olması gerekir. COVID-19, yapılan işin niteliğinden veya yürütüm şartlarından kaynaklanan bir sebeple bulaşmadığ için meslek hastalığı olarak değerlendirilemez. COVID-19 hastalığı, bulaşıcı bir hastalıktır ve yapılan iş ile ilgili değildir. Mesleğe bağlı olmadan ortaya çıkmaktadır. Salgın geçici bir durumdur. Sürekliliği olmadığı için mesleki sayılmamalıdır. Meslek hastalığı olabilmesi için tekrarlanan bir sebeple devam etmesi gerekir. Korona virüsünün bulaşması ise ani olmaktadır. İş kazasındaki anilik unsuru, Korona virüs bulaşan işçinin durumunun iş kazası sayılması ihtimalini güçlendirmektedir ${ }^{92}$. Bu sebeple sağlık çalışanları bakımından da COVID-19 hastalığının meslek hastalığ olarak değerlendirilmemesi gerektiği; zira COVID-19 hastalığına yakalanmanın, sağlık çalışanları bakımından da işin yürütüm şartlarından doğmadığı gibi işyeri şartlarından da oluşmadığı belirtilmiştir. Bununla birlikte Korona virüsün bulaşması sebebiyle, işçinin akciğerlerinde sürekli, kalıcı bir hastalık durumu ve giderek sürekli iş göremezlik oluşursa COVID-19 hastalığının, meslek hastalığı olarak nitelendirilebileceği de ileri sürülmüştür ${ }^{93}$. Alman öğretisinde iş kazasının kısa bir zaman diliminde, meslek hastalığının ise uzun bir zaman diliminde ortaya çıkmasının mutlak olmadığı belirtilmektedir. Dolayısıyla meslek hastalıkları listesinde yer alan bir hastalığın zararlı etkene bir defa veya kısa süreli maruz kalmak yoluyla ortaya çıkabileceği ifade edilebilir ${ }^{94}$.

Öğretide diğer görüşe göre ise, sağlık çalışanları bakımından COVID-19 hastalı̆̆1, çalışanların hastane ortamında virüse yakalanmış olmaları halinde meslek hastalığ olarak değerlendirilmelidir ${ }^{95}$. İşin yürütümü gereği hastalarla çok yakın temas halinde

\footnotetext{
"Yakın temasl, bilinen ve şüphelenilen COVID-19 vakasında aerosol üreten prosedürler; numune toplama ve işleme prosedürleri, ölen vakaların otopsi prosedürlerini içeren iş kolları (Doktorlar, hemşireler, diş hekimleri, sağlık görevlileri, acil tıp teknisyenleri, numune toplayan sağlık ve laboratuvar personeli, otopsi yapan morg çalışanı)", COVID-19 Pandemisi'nde Meslek Hastalığı Tanı Kılavuzu, s. 8, 9, <https://www.istabip.org.tr/koronavirus/Haberler/5578/covid-19pandemisi-nde-meslek-hastaligi-tani-kilavuzu> Erişim Tarihi 25 June 2020.

91 COVID-19 Pandemisi'nde Meslek Hastalı̆̆ı Tanı Kılavuzu, (n 90) 8.

92 Yürekli (n 6) 45; Balcı (n 76); Yener (n 45) 110; Sami Narter and Cebrail Şimşek, 'Sağlık Çalışanları İçin COVID-19 Hastalı̆̆ı İş Kazası veya Meslek Hastalığı Mıdır?' (2020/16) Karatahta İş Yazıları Dergisi 139, 163 vd.

93 'COVID-19 Pandemisi Günlerinde İş Kazası ve Meslek Hastalığı Rehberi’ (n 86) 3.

$94 \quad$ Akdeniz (n 77) 21.

95 Caniklioğlu (n 43); Bulut (n 69) 100; Yener (n 45) 110; 'COVID-19 Pandemisi Günlerinde İş Kazası ve Meslek Hastalığı Rehberi', (n 86) 2.
} 
olmaları, sağlık çalışanlarını riskli gruba dâhil etmektedir. Bu sebepledir ki sağlık çalışanları bakımından nedensellik bağı daha kolay kurulabilir.

Güç Kaybı Yönetmeliği ile meslek hastalıklarının bir liste halinde sayıldığı daha önce belirtilmişti. Güç Kaybı Yönetmeliğinin ekindeki Meslek Hastalıkları Listesi'nin (D) Grubunda Mesleki Bulaşıcı Hastalıklar düzenlenmiştir. Güç Kaybı Yönetmeliği madde 19/1'de Mesleki Bulaşıcı Hastalıklar Listesinin(D) Grubunda yer alan bulaşıcı hastalıkların, görülen işin gereği olarak veya işyerinin özel koşullarının etkisiyle oluşması ve enfeksiyonun laboratuvar bulguları ile de kanıtlanmasının gerekli olacağı belirtilmiştir. Aynı maddenin ikinci fikrasına göre, mesleki bulaşıcı hastalıklar listesinde yer almayan fakat görülen iş ve görev gereği olarak bulaştığı kesin olarak saptanan diğer bulaşıcı hastalıklar da meslek hastalığı sayılacaktır. $\mathrm{Bu}$ husustaki teşhisin laboratuvar deneyleriyle kanıtlanması gereklidir. Hastalığın en uzun kuluçka süresi yükümlülük süresi olarak alınacaktır. Söz konusu Meslek Hastalıkları Listesinde COVID-19 hastalığı yer almamaktadır. Bununla birlikte anılan Yönetmeliğin ikinci fikrası gereği COVID-19 hastalığı (D) Grubunda yer alan mesleki bulaşıcı hastalıklardan sayılabilir. Diğer taraftan bir hastalığın Listede sayılmaması o hastalığın meslek hastalığı sayılmayacağı anlamına da gelmemelidir. 5510 say1lı Kanun madde 14/son gereğince Güç Kaybı Yönetmeliğinde belirlenmiş hastalıklar dışında herhangi bir hastalığın meslek hastalığı sayılıp sayılmaması hususunda çıkabilecek uyuşmazlıklar, Sosyal Sigorta Yüksek Sağlık Kurulunca karara bağlanacaktır.

\section{Sonuç}

COVID-19 hastalığı, 5510 sayılı Kanunda yazılı koşullar çerçevesinde ortaya çıkarsa iş kazası olarak nitelendirilebilecektir. Sigortalının işyerinde bulunduğu sırada Korona virüse yakalanması, şüphesiz ki iş kazası olarak değerlendirilmelidir. İşveren tarafindan verilen emir ve talimatları yerine getirirken işçinin virüsle enfekte olması da aynı kapsamdadır. Yine işveren tarafından yürütülmekte olan iş nedeniyle bir müşterinin evinde musluk tamiri için gittiği sırada, işçinin müşteriden Korona virüsü kapması da iş kazasıdır. Sigortalı görevli olarak işyeri dışında başka bir yere gönderildiğinde, toplu taşıma araçlarını kullanırken Korona virüsü ile enfekte olması durumu iş kazası sayılacaktır. Zira işverence sağlanan bir taşıt olmasa bile işverenin otoritesi devam etmektedir. Aynı şekilde emziren kadın sigortalının çocuğuna süt vermek için ayrılan süt izni içinde işyerine gidiş gelişinde toplu taşıma aracını kullanırken Korona virüse yakalanması halinde iş kazası gündeme gelebilecektir. İşverence sağlanan servis aracında sigortalının işin yapıldığı yere gidiş gelişi sırasında virüs bulaşması da iş kazası sayılacaktır. Bu örnekleri çoğaltmak mümkündür ancak olası bir yargılamada tespit edilmesi gereken, COVID-19'un işçiye ne zaman ve nasıl bulaştığıdır. Olması gereken, her COVID-19 hastalığını iş kazası saymak yerine, 
nedensellik bağının olduğu olayları iş kazası saymak olmalıdır. COVID-19'un 2-14 günlük kuluçka süresi de dikkate alınarak virüsün 5510 sayılı Kanun madde 13'te yazılan unsurlardan birinde bulaştığının kanıtlanması gerekir.

İşçinin sadece Korona virüs testinin pozitif çıkması iş kazası sayılması için yeterli olmayacak; virüs sonucunda sigortalının bedensel veya ruhsal bir zarara uğraması gerekecektir. Korona virüs sigortalının akciğeri üzerinde büyük bir hasar bırakmış olabilir veya sigortalı geçirdiği hastalık sonucu vefat etmiş olabilir. Veyahut virüse yakalanma olayı sigortalıda ruhsal bir engel yaratmış olabilir. Bütün bunlar sigortalının enfekte olduğu virüs sonucu bedensel veya ruhsal bir zarara uğradığını gösterir.

Bir kazanın sosyal güvenlik hukuku bakımından iş kazası sayılması ile iş hukuku bakımından iş kazası sayılması kavramları birbirinden farklıdır. 5510 sayılı Kanuna göre iş kazası sayılan bir durumda, Sosyal Güvenlik Kurumu tarafindan sigorta yardımları yapılır. Sigorta yardımlarının yapılabilmesi için işverenin kusurlu olması şartı aranmamaktadır. Daha açık bir ifadeyle bir olayın iş kazası olarak nitelendirilmesi, her zaman işverenin hukuki veya cezai sorumluluğunu doğurmayabilir. İşverenin iş kazasından hukuki sorumluluğunun doğabilmesi için kaza ile yapılan iş arasında uygun nedensellik bağının kurulması gerekir. İşverenin iş sağlı̆̆1 ve güvenliği yükümlülüklerine uymaması sebebiyle sorumluluğu söz konusu olacaktır. Bu nedenle işçi, COVID-19 hastalığından dolayı bir zarara uğrarsa, işverenin sorumlu olabilmesi için kusurlu olması gerekecektir. İşçi ve işverenin sorumluluğunun tespitinde kaçınılmazlık ilkesi de dikkate alınmalıdır.

Yargıtayın 2019 tarihli H1N1 virüsüne (domuz gribi) bağlı olarak meydana gelen ölümü iş kazası olarak kabul ettiği kararının Korona virüsü (COVID-19 hastalığı) bakımından da emsal teşkil etmesi gerektiği kanaatindeyiz. Yargıtay bu kararında sonradan oluşan zarar ile olay arasında uygun illiyet bağının bulunduğunu belirtmiştir. COVID-19 hastalığında da aynı şekilde kuluçka süresine bağlı olarak sonradan oluşan hastalık durumu veya vefat halinin iş kazası olduğunun kabulü gerekmektedir. Zira Yargıtayın da belirttiği gibi 5510 sayılı Kanun madde 13 hükmü, sosyal güvenlik hukuku ilkeleri içinde değerlendirilerek geniş yorumlanmalıdır.

COVID-19'un meslek hastalığı bakımından değerlendirilmesinde konunun sağlık çalışanı için ayrı bir değerlendirmeye tabi tutulması gerektiği kanaatindeyiz. Sağlık çalışanı, ister kamu isterse de özel sağlık kuruluşunda çalışsın, sağlık çalışanının COVID-19 hastalığına yakalanması durumu, meslek hastalığı olarak değerlendirilebilir. Meslek hastalığı olarak nitelendirilebilmesi için, sağlık çalışanının COVID-19 hastalığına yakalanması ve tedavi olsa dahi buna bağlı olarak sürekli bir akciğer hastalığının oluşması ve maluliyet durumunun ortaya çıkması gerekmektedir. 
Hakem Değerlendirmesi: Dış bağımsız.

Çıkar Çatışması: Yazar çıkar çatışması bildirmemiştir.

Finansal Destek: Yazar bu çalışma için finansal destek almadığını beyan etmiştir.

Peer-review: Externally peer-reviewed.

Conflict of Interest: The author has no conflict of interest to declare.

Grant Support: The author declared that this study has received no financial support. 


\section{Bibliyografya/Bibliography}

Akdeniz AL, Meslek Hastalığı Kavramı Üzerine, (Beta 2015).

Akın L, ‘COVID-19’un İş İlişkilerine Olası Etkileri’ (2020) 34(3) Çimento İşveren Dergisi, 16-71 (COVID-19'un İş İlişkilerine Etkileri).

Akın L, 'İşverenin İşçiyi Gözetme Borcundan Doğan Hukuki Sorumluluğunda Uygun Nedensellik Bağı’ (Karar İncelemesi) (Mart 2011) Çimento İşveren Dergisi, 26-39 (Nedensellik Bağı).

Akın L, İş Kazasından Doğan Maddi Tazminat (Yetkin 2001).

Arslan S, 'İş Sağlığı ve Güvenliği Kanunu'na Göre İşverenin Genel Yükümlülükleri’ (2014) 20(1) MÜHFHAD, Özel Sayı, Prof. Dr. Ali Rıza Okur’a Armağan, 767-807.

Ateş ZG, ‘COVID-19’un İşverenin İş Sağlığı ve Güvenliği Konusunda Alması Gereken Önlemlere Etkisi’, (2020) 19(38) İstanbul Ticaret Üniversitesi Sosyal Bilimler Dergisi, COVID-19 Hukuk Özel Sayıs1, 161-179.

Balc1 M, 'Covit-19'un İş Güvenliği Yönünden Hukuki Nitelendirmesi', Türkiye Barolar Birliği Eğitim Merkezi Online Eğitim Programları, TBB TV, 29 Nisan 2020, <https://www.youtube. com/watch?v=RwHqOMwMqq8>, Erişim Tarihi 7 June 2020.

Baycık G, 'Sosyal Güvenlik Kurumunun İş Kazası veya Meslek Hastalığından Kaynaklanan Rücu Davalarına Eleştirel Bakış’ (2017) 7(1) Sosyal Güvenlik Dergisi, 31-70.

Bulut M, 'Türkiye'de Pandemi Sürecinde İş Sağlığ ve Güvenliği Mevzuatına İlişkin Meseleler' (2020), Koronavirüs Döneminde Güncel Hukuki Meseleler Sempozyumu Bildiri Özeti Kitabı, İbn Haldun Üniversitesi Yayınları, 99-107.

Canbolat T and Kayırgan H, 'Korona Virüs Salgınının İş Sözleşmesi ile İşçi İşveren İlişkilerine Etkisi ve Sonuçları', (2020) 5(1) Çankaya Üniversitesi Hukuk Fakültesi Dergisi Arş. Gör. Ceren Damar Şenel Armağanı, 637-688.

Caniklioğlu N, 'Sosyal Sigorta Türleri Açısından Yargıtayın 2002 Yılı Kararlarının Değerlendirilmesi', (2004) İş Hukuku ve Sosyal Güvenlik Hukuku Türk Milli Komitesi 339393 (Değerlendirme 2002).

Caniklioğlu N, ‘6331 Sayılı İş Sağlığı ve Güvenliği Kanununda Öngörülen İşveren Yükümlülükleri’ (2012) Türkiye Toprak, Seramik, Çimento ve Cam Sanayii İşverenleri Sendikası, Çalışma Mevzuatı Seminer Notları, Antalya, 26-30 Eylül 2012, 27-84 (İşveren Yükümlülükleri).

Caniklioğlu N, Koronavirüs Döneminde Güncel Hukuki Meseleler Sempozyumu, İbn Haldun Üniversitesi, 29.05.2020, <https://www.youtube.com/watch?v=sQPmdcI-G4c > Erişim Tarihi 10 June 2020.

Çelik N, Caniklioğlu N and Canbolat T, İs Hukuku Dersleri (32th edition, Beta, 2019).

Ekmekçi Ö, 4857 Sayılı Işs Kanunu'na Göre İş Sağlı̆̆ı ve Güvenliği Konusunda İşyeri Örgütlenmesi, (Legal 2005).

Eren F, Borçlar Hukuku Genel Hükümler (21th edition, Yetkin, 2017) (Borçlar Genel).

Eren F, Sorumluluk Hukuku Açısından Uygun Illiyyet Bağı Teorisi, (Ankara Üniversitesi Hukuk Fakültesi Yayınları No:361 1975).

Güzel A, Okur AR and Caniklioğlu N, Sosyal Güvenlik Hukuku (18th edition, Beta 2020).

Keser H, 'Korona Virüs (Covid 19) Özelinde Bir Salgın Durumunda İş Mevzuatı Kapsamında İşçi ve İşverenin Kullanabileceği İzin, Esnek Çalışma Süreleri ve Fesih Hakları Üzerine Bir Değerlendirme' (2020) 17(65) Legal İSGHD, 23-94.

Narter S and Şimşek C, 'Sağlık Çalışanları İçin COVID-19 Hastalığı İş Kazası veya Meslek Hastalığı Mıdır?' (2020/16) Karatahta İş Yazıları Dergisi 139-168. 
Okur Z, 'Yargıtay Kararları Çerçevesinde İş Kazası' (2013), VII. Ulusal İşçi Sağlığı ve İş Güvenliği Kongresi Bildiriler Kitab1 18-20 Nisan 2013, 325-331.

Özdemir E, İ̧ Să̆lı̆̆ ve Güvenliği Hukuku, (Vedat 2014).

Özveri M, 'Pandemi Sürecinin İş Hukukuna Yansımaları', (2020) İzmir Barosu Bülten, İş ve Sosyal Güvenlik Hukuku Komisyonu Pandemi Özel Bülteni, 25-38.

Sözer AN, Türk Sosyal Sigortalar Hukuku, (4th edition, Beta 2019).

Sümer HH, İs Să̆lı̆̆ ve Güvenliği Hukuku (3th edition, Seçkin 2019).

Süzek S, İş Hukuku (16th edition, Beta 2018).

Tuncay C, 'Kurumun İşverene Rücuu-Olayda Kaçınılmazlık Durumu’ (Aralık 2006)(4) Sicil İHD $183-188$.

Tuncay C and Ekmekçi Ö, Sosyal Güvenlik Hukuku Dersleri, (20th edition, Beta 2019).

Yamakoğlu E, Işsverenin İsyeri Hekimi ve Işs Güvenliği Uzmanı Çalıştırma Yükümlülüğü, (Seçkin 2016).

Yener MZ, 'COVID-19 Salgınının İş Kazası ve Meslek Hastalığı Bakımından Değerlendirilmesi' (2020) Koronavirüs Döneminde Güncel Hukuki Meseleler Sempozyumu Bildiri Özeti Kitabı, İbn Haldun Üniversitesi Yayınları, 108-117.

Yürekli S, 'Çalışma Hayatında Koronavirüs (COVID-19) Salgınının Etkileri' (2020) 19(38) İstanbul Ticaret Üniversitesi Sosyal Bilimler Dergisi, COVID-19 Hukuk Özel Sayıs1, 34-61.

\section{Elektronik Kaynaklar}

$<$ www.kazanci.com>

$<$ https://www.who.int/health-topics/coronavirus\#tab=tab_1, Erişim Tarihi 13 June 2020.

T.C. Sağlık Bakanlığı Halk Sağlığı Genel Müdürlüğü, "COVID-19 (Sars-Cov-2 Enfeksiyonu), Genel Bilgiler, Epidemioloji ve Tanı, Bilimsel Danışma Kurulu Çalışması, Ankara, 1 Haziran 2020, s. 5, <https://covid19bilgi.saglik.gov.tr/depo/rehberler/covid-19-rehberi/COVID-19_REHBERI GENEL_BILGILER_EPIDEMIYOLOJI_VE_TANI.pdf $>$ Erişim Tarihi 13 June 2020.

$<$ https://www.ailevecalisma.gov.tr/media/40969/isyerlerinde-koronaviruse-covid-19-karsialinmasi-gereken-onlemler.pdf> Erişim Tarihi 14 June 2020.

$<$ https://covid19bilgi.saglik.gov.tr/tr/sss/halka-yonelik.html> Erişim Tarihi 16 June 2020.

$<$ https://covid19bilgi.saglik.gov.tr/tr/> Erişim Tarihi 22 June 2020.

COVID-19 Pandemisi'nde Meslek Hastalığ Tanı K1lavuzu, s. 8, 9, <https://www.istabip.org.tr/ koronavirus/Haberler/5578/covid-19-pandemisi-nde-meslek-hastaligi-tani-kilavuzu> Erişim Tarihi 25 June 2020.

'COVID-19 Pandemisi Günlerinde İş Kazası ve Meslek Hastalığı Rehberi', İstanbul Tabip Odası Hukuk Bürosu, 25.04.2020, s. 1, <https://www.istabip.org.tr/site_icerik/2020/mayis/covid_19_ is_kazasi_meslek_hastaligi.pdf>, Erişim Tarihi 25 June 2020.

$<$ https://www.who.int/hrh/statistics/Health_workers_classification.pdf $>$ Erişim Tarihi 25 June 2020.

$<$ https://drive.google.com/file/d/1wyqKwK18db87PkEtfBO4FgrHBM9FY3tt/view> Erişim Tarihi 26 June 2020.

$<$ https://covid19bilgi.saglik.gov.tr/depo/toplumda-salgin-yonetimi/salgin-yonetimi-ve-calismarehberi/COVID-19_SALGIN_YONETIMI_VE_CALISMA_REHBERI.pdf> Erişim Tarihi 26 June 2020 . 
